\title{
Post-Conflict Aid, Real Exchange Rate Adjustment, and Catch-up Growth (*)
}

\author{
Ibrahim A. Elbadawi \\ Development Economic Research Group \\ World Bank, Washington DC \\ email: ielbadawi@worldbank.org
}

\author{
Linda Kaltani \\ Development Economic Research Group \\ World Bank, Washington DC \\ email: 1kaltani@worldbank.org
}

\author{
Klaus Schmidt-Hebbel \\ Banco Central de Chile \\ email: kschmidt@,bcentral.cl
}

\begin{abstract}
$\underline{\text { Abstract }}$
Post-conflict countries receive substantial aid flows after the start of peace. While post-conflict countries' capacity to absorb aid (i.e., the quality of their policies and institutions) is built up only gradually after peace onset, the evidence suggests that aid tends to peak immediately after peace is attained and decline thereafter. Aid composition broadly reflects post-conflict priorities, with large parts of aid financing social expenditure and infrastructure investment. While moderate RER overvaluation is observed in postconflicts, it cannot be traced down to the aid flows. The empirical evidence on world growth reveals new findings about the pattern of catch-up growth during post-conflicts and the role of key growth determinants on post-conflict growth. Aid is an important determinant of growth, both generally and more strongly during post-conflict periods. Because RER misalignment reduces growth, RER overvaluation during post-conflicts reduces catch-up growth. Aid and RER overvaluation combined also lower growth. However, the negative growth effect of RER overvaluation declines with financial development.
\end{abstract}

\section{World Bank Policy Research Working Paper 4187, April 2007}

The Post-Conflict Transitions Working Paper Series disseminates the findings of work in progress to encourage the exchange of ideas about post-conflict development (more information about the Post-Conflict Transitions Project can be found at http://econ.worldbank.org/programs/conflict ). An objective of the series is to get the findings out quickly, even if the presentations are less than fully polished. The papers carry the names of the authors and should be cited accordingly. The findings, interpretations, and conclusions expressed in these papers are entirely those of the authors. They do not necessarily represent the views of the World Bank, its Executive Directors, or the countries they represent. Policy Research Working Papers are available online at http:/lecon.worldbank.org.

(*) A preliminary version of this paper was presented at the first collaborative research project workshop on "Political Institutions, Development and a Domestic Civil Peace: PIDDCP”, Oslo, Norway, June 19-20, 2006, organized by the Development Economic Research Group (DECRG) of the World Bank; The Centre for the Studies of the African Economies (CSAE), University of Oxford, and the International Peace Research Institute (PRIO) of Oslo. The authors thank Paul Collier and Majak d'Agoot, and workshop attendants for valuable comments and suggestions. Also Ibrahim Elbadawi and Linda Kaltani would like to thank Norman Loayza and Aart Kraay for helpful discussions. The views expressed in this paper are not necessarily those of the Banco Central de Chile or of the World Bank, its Board of Directors or affiliated organizations. The authors acknowledge the valuable research support of Nahla Hilmi and Marcelo Ochoa. 


\section{Introduction}

Countries coming out of civil wars usually have large needs, both humanitarian and developmental. Therefore, aid or Official Development Assistance (ODA) can play an important role in the post-conflict reconstruction of these economies, as well as in consolidating peace and reducing risks of future conflicts. And because of the large potential for catch-up growth in post-conflict countries, their economies tend to have high absorptive capacities and aid can be potentially very effective, even with modest improvements in the institutional and policy environments. However, aid-recipient countries would need to spend aid wisely, which would require not only good economics but also good politics. The latter is important because the same cleavages that underlie civil wars are likely to be at work after the end of conflicts. Therefore both good economic management and strong political processes, relying on transparency and accountability, will be needed for aid to be effective in post-conflict experiences. Donors also have to do their part for this potential to be realized for a long enough period to allow these countries to return to normalcy. Aid delivery mechanisms must promote ownership, transparency, and wide stakeholder participation in the development process.

The latter are well-known issues in the aid effectiveness literature and have already attracted considerable academic and policy interest. This paper, however, addresses other issues regarding the impact of large ODA flows - a typical post-conflict phenomenon on the real exchange rate (RER) and on growth. In this context we will address the following questions: what have been the time profile and composition of ODA during the post-conflict cycle? Has post-conflict aid been associated with disequilibrium real exchange rate appreciation? How serious was RER misalignment in post-conflict and how much of RER misalignment is explained by large post-conflict aid flows? What impact does RER misalignment, especially extreme real exchange rate overvaluation, have on growth and aid effectiveness?

As an economy-wide relative price influencing inter and intra-temporal expenditure and resource allocation decisions, the real exchange rate has a potentially important influence on export growth, export diversification, and economic growth. ${ }^{1}$ In turn, ODA is a key determinant of the RER, through its influence on domestic spending and saving decisions. The more aid is spent, the larger is spending on non-traded goods and services, and the larger is the share of aid that is saved to build up net domestic-currency publicsector assets, the larger is the ensuing RER appreciation, with potential negative effects on output and employment - the so-called Dutch disease. In this context, excessive aid dependence could have a detrimental impact on non-traditional exports and thus undermine an effective source of dynamic growth.

\footnotetext{
${ }^{1}$ The real exchange rate concept adopted here is reflects the economy-wide relative price of non-traded to traded goods, proxied by real effective real exchange measures. A rise (decline) in the latter means an RER appreciation (depreciation). The RER is judged to be misaligned when it diverges from its equilibrium level (ERER), where the latter is derived from a behavioral model that accounts for equilibrium in the non-traded goods markets as well the inter-temporal implications of current account sustainability. The misaligned RER is characterized as overvalued (undervalued) when the actual RER is larger (smaller) than its corresponding equilibrium level.
} 
The central role of the RER is confirmed by evidence suggesting that protracted RER overvaluation tends to be associated with lower economic growth. ${ }^{2}$ And, given that overall economic activities might be partially boosted by an overvaluation-driven growth in the non-tradable sector, the impact may be particularly harmful to export growth and economic diversification, ${ }^{3}$ especially if export production is characterized by learning-by-doing externalities and capital market imperfections as in the cases of nontraditional and especially manufacturing exports. ${ }^{4}$ In addition, the level of the real exchange rate affects competitiveness directly, through the return to investing in tradedgoods industries, and indirectly, by influencing exploitation of comparative advantage. ${ }^{5}$ Although it may not be of immediate concern to low-income post-conflict countries, recent literature also finds that persistent RER overvaluation is a powerful predictor of currency crises. ${ }^{6}$

Section 2 analyzes the size, timing, and composition of post-conflict aid during the postconflict cycle, as well as ODA-RER correlations, in a sample of 32 countries and with more detailed focus on 7 country cases. Section 3 reports estimation results for the RER, based on a world sample of 83 countries and annual 1980-2004 data, focusing on the role of aid on the long-term RER behavior. This allows subsequently to derive measures of RER misalignment for different sub-periods in the pre and post-conflict cycle and to trace the influence of large aid flows on RER overvaluation in post-conflicts. Section 4 reports estimation results for growth, based on a world sample of 78 countries and 5-year data spanning from 1970 to $2004 .^{7}$ The growth specification allows testing for the influence of the post-conflict cycle, foreign aid, and RER misalignment on growth, controlling for standard growth determinants and allowing for key interactions between post-conflict periods, aid, RER misalignment, and financial development. Section 5 concludes.

\section{Aid and Dutch Disease during Post-Conflicts}

Post-conflict countries tend to experience substantial surges of aid flows, which have potential consequences for their competitiveness and growth behavior. To understand the latter, we start by reviewing briefly the basics of aid management and its implications for the RER.

The receiving government faces two basic choices in its use of aid: it can spend or save it. One extreme for the government is to spend aid fully, increasing its non-aid public deficit accordingly. If government spending falls entirely on traded goods (for example, on imports of school computers and textbooks), the trade deficit and hence the non-aid

\footnotetext{
${ }^{2}$ See, for example, Edwards (1989), Cottani et al. (1990), Ghura and Grennes (1993), Razin and Collins (1997), Easterly and Levine (1997), and Aguirre and Calderón (2005).

${ }^{3}$ See, for example, Nabli and Veganzsones-Varoudakis (2002) and Elbadawi (2002).

${ }^{4}$ See, for example, van Wijnbergen (1986).

${ }^{5}$ This problem has been extensively documented in the case of Africa by, among others, Elbadawi (2002), Mengistae and Pattillo (2004), and Dufrenot and Yehoue (2005).

${ }^{6}$ See, for example, Kaminsky et al. (1998) and Merrill Lynch (1998).

${ }^{7}$ The RER model can only be estimated for the shorter period (1980-2004) because the error-correction panel estimation methodology requires full data availability. However, the estimated model can be used to construct indexes of RER equilibrium and RER misalignment for the longer 1970-2004 period.
} 
current account deficit rise by the magnitude of the aid inflow. In the latter case, aid is fully absorbed, the resource transfer from abroad to the recipient economy is complete, and the RER is likely to appreciate by little, if anything. By contrast, if aid is fully spent by the government on non-traded goods (for example, labor-intensive social services or reconstruction of domestic infrastructure), absorption of aid is very limited (the non-aid current account changes by little), but the RER is likely to appreciate significantly.

The other extreme choice for the government is not to spend aid but to save it, by building up its net asset position, which typically is weak after the end of conflict. In this case, the government can use aid by increasing its own or the central bank's international reserves or by reducing public-sector debt. Debt reduction can be implemented by amortizing outstanding public debt or reducing new debt flows - in both cases the government uses aid to strengthen its debt position, avoiding an increase in government spending or a reduction in government revenue. If the government decides to increase international reserves or reducing foreign debt, the RER appreciates by little, if anything. However, if the government uses foreign-currency aid to pay back domestic-currency denominated domestic debt - an operation equivalent to a central bank sterilized forex intervention - the corresponding private-sector portfolio shift could lead to RER appreciation.

The latter description is simple because it abstracts from an explicit discussion of privatesector reaction, financial-market features, and monetary and exchange-rate policy considerations. ${ }^{8}$ However, it identifies the main factors that determine the RER response to government use of foreign aid: spending vis-à-vis saving, the sector composition of government spending, and the currency composition of public saving. RER appreciation will be larger the more governments spend, the larger is the share of spending falling on non-traded goods, and the larger is the share of public-sector saving falling on net domestic-currency assets.

The RER appreciation leads to private-sector expenditure switching from traded to nontraded goods and resource allocation from traded to non-traded production sectors, further widening the current-account deficit. Resource allocation may be slow and costly, leading to temporary but protracted reduction in aggregate output and employment. The decline in exports and traded-goods production due to the loss in international competitiveness may lead to lower productivity gains - often concentrated in tradedgoods activities and particularly in export sectors - lowering economic growth. This result - termed Dutch disease - has often been associated to commodity price booms but may also be observed during post-conflict aid surges - a central issue of this paper.

\footnotetext{
${ }^{8}$ IMF (2005) and Aiyar et al. (2005) provide a discussion of the accounting features and qualitative aspects of the macroeconomics of foreign aid. The appropriate way to analyze the macroeconomics of aid is by using a dynamic general-equilibrium framework, with explicit modeling of endogenous private sector expenditure, resource-allocation, and portfolio reactions to government spending and saving decisions in response to aid, giving rise to endogenous determination of the current account, the real exchange rate, domestic interest rates, risk premiums, and portfolio composition, as well as all relevant sector prices and quantities. Moreover, a general equilibrium framework is also the suitable way to address the problems of aid additionality and resource fungibility, by allowing to spell out explicit counterfactuals. However, a full general-equilibrium framework is well beyond the scope of this paper.
} 
Much of the literature on Dutch disease deals with the macroeconomic and growth effects of commodity discoveries and price booms. From a theoretical point of view, the change in the composition of output from traded to non-traded sectors has ambiguous effects on growth in the long run. Van Wijnbergen (1984) and Krugman (1987) suggest that the effects of foreign resource inflows depend on the magnitude and persistence of the inflows. If the commodity resource flow is sufficiently prolonged, traded-sector competitiveness is reduced and production of non-commodity traded goods will suffer. In contrast, Sachs and Warner (1995) argue that the negative growth effect will be temporary and in the long-run growth will not be affected. More recent empirical evidence tends to conclude that the effects of abundant resource inflows depend on institutional development and the corruption and rent-seeking behavior elicited by the resource inflows. Spatafora and Warner (1999) show that in a sample of 18 oil-exporting countries, the RER appreciation led to an enlarged non-traded sector, but there is no evidence of a contraction of the traded-goods sector. In contrast, Sachs and Warner (1999) find that per-capita GDP declined or remained constant after the discovery of natural resources. The implication of the literature on resource booms is that post-conflict governments receiving aid surges have reasons to be concerned about potential aidinduced RER appreciation that may damage competitiveness and growth prospects.

Some important findings and policy implications are noted by the expanding academic and operational literature on aid effectiveness in post-conflict experiences. ${ }^{9}$ In evaluating government use of aid, Barder (2006) notes that there are limits on "aid absorption", which might explain why the costs of aid increase faster than its benefits. Collier and Dollar (2002) find that aid effectiveness is subject to diminishing returns, but the absorptive capacity of aid-receiving countries is primarily explained by the quality of their policies and institutions.

More generally, the choice between spending and saving foreign aid by recipient governments is shaped by a large number of country and post-conflict specific factors. The latter choice implies balancing the needs of quick spending - including humanitarian aid delivery, restoration of social spending, and infrastructure reconstruction needs - and the benefits of saving much of aid - including building up government asset positions, avoiding Dutch disease, and spending more slowly in accordance with estimated permanent aid flows. The latter economic factors are complemented by domestic political-economy considerations, the quality of domestic policies and institutions, and donor conditionality imposed on aid disbursement.

Considering the latter diverse economic and political factors that shape aid spending/saving decisions, it is an empirical matter of how post-conflict countries have dealt with aid flows. We will assess this empirical evidence by analyzing the experience of a significant sample of post-conflict aid-recipient countries and highlighting a few specific country cases.

\footnotetext{
${ }^{9}$ See for example, Collier and Hoeffler (2002), Clements, Radelet and Bhavnani (2004), Addison (2003), Kang and Meernik (2004), Weiss (2004), IMF (2005), and Schwartz et al. (2006).
} 
Our sample covers 36 post-conflict countries for which the ending years of conflicts range from the 1960s to the 2000s. In order to identify periods of conflict along with the start and end dates of wars, we use the definition of civil war and the data presented in Sambanis (2004) and PRIO (2005). ${ }^{10}$ The literature suggests that in the ten years following the end of conflicts, growth follows a fairly robust pattern. The capacity of these economies to absorb aid effectively also increases over the post-conflict cycle (Collier and Hoeffler 2002). ${ }^{11}$ We closely follow the latter authors in defining three postconflict sub-periods, to which we add a pre-peace period (prior to the end of conflict) to allow for a more comprehensive comparison. Hence we define the conflict cycle as follows, where year 0 indicates the year when peace is attained:

- PrePeace $\{\mathrm{yr}(-4), . ., \mathrm{yr}(-1)\}$ : covers the four years prior to the year of peace

- PeaceOnset $\{\mathrm{yr}(0), \mathrm{yr}(1)\}$ : covers the first two peaceful years, including the year when peace is attained

- PostConf1 $\{\operatorname{yr}(2), . ., \mathrm{yr}(5)\}$ : covers the following four peace years

- PostConf $2\{\mathrm{yr}(6), . ., \mathrm{yr}(9)\}$ : covers the subsequent peace years.

Figure 1 summarizes aid flows during the post-conflict cycle for the median conflict country. Post-conflict countries receive larger aid with the start of peace. The median Official Development Aid (ODA) rises from 4\% during PrePeace to 5\% in PeaceOnset, with a relapse to $4 \%$ during PostConf1 and PostConf2. The corresponding rise in percapita aid is about US\$ 6 per capita per year between PrePeace and the six years after peace (PeaceOnset and PostConf1). ${ }^{12}$ Generally ODA tends to peak early, during the PeaceOnset period. However, the quality of policies and institutions of conflict countries improves, at least modestly, with the start of peace. According to the World Bank's Country Policy and Institutional Assessment (CPIA), the corresponding quality indicator rises somewhat after peace for our median conflict country, suggesting an improved capacity to absorb aid.

Humanitarian or emergency aid tends to be more erratic, depending on the extent of country-specific emergency situations. Examples of large humanitarian receipts include the cases of Mozambique after the natural catastrophe in 2000 and Rwanda after the 1994 genocide, where humanitarian aid attained more than $\$ 0.15$ per capita. For the median country in our sample, emergency aid grew exponentially in the post-conflict period, from \$ 0.09-0.10 during PrePeace and PeaceOnset to \$0.15 during PostConf1 and \$ 0.41 during PostConf2.

Collier and Hoeffler (2002) find that during PeaceOnset the economy is likely to experience only a moderate rise in growth and the capacity for absorbing ODA is likely to be limited. In contrast, during PostConf1 and PostConf2 growth picks up and the capacity of aid absorption also grows. The peak of aid during PeaceOnset and its

\footnotetext{
${ }^{10}$ Appendix A presents a list of conflict countries with the date(s) when the conflict(s) ended.

${ }^{11}$ See also Elbadawi (2006) for an analysis of the case of post-conflict Sudan.

${ }^{12}$ By these estimates, a median country of 30 million people receive roughly US\$180 m. per annum more in aid after peace than with what it received before the end of conflict.
} 
subsequent decline during years 2-9 after the start of peace stands in contrast to the gradual rise in absorptive capacity and in growth observed over the post-conflict decade.

Our evidence suggests that donors may provide too much aid too early and reduce aid flows too quickly, just when post-conflict economies are ready to absorb more aid. Donor decisions regarding ODA allocation to post-conflict countries are determined by several factors, most notably poverty, although their aid decisions are often dominated by their sheer political interests (Kang and Meernnik 2004). For example, donor countries that intervene militarily in a conflict, whether to aid or defeat a regime, are likely to emerge as the most important contributors to post-conflict relief and reconstruction efforts. Political transition is another important determinant. Donors tend to be more generous to countries that are likely to implement a democratic transition as part or consequence of the peace process. Aid is also likely to be higher the larger are trade relations or other bilateral economic interests between donor and recipient countries. These considerations may lead to important cross-country differences in aid patterns.

What is the composition of aid and its evolution over the post-conflict cycle and does it reflect the development priorities of post-conflict periods, such as the need for service delivery in education and health or rebuilding infrastructure? There is some consensus that aid in post-conflict settings ought to be broad-based and pro-poor (e.g. Collier and Hoeffler, 2002). It has been argued that the scope for rapid reform is greater in postconflict settings and therefore there is less need to limit reform to a few interventions with rapid payoffs. Also, due to the high risk that post-conflict countries may return to war, peace-promoting policies have to be supported early on. Moreover, unless policies are explicitly pro-poor, reconstruction efforts risk to being narrow, benefiting mostly the elite. If legitimate employment prospects and wages are depressed, demobilized excombatants will face few job opportunities other than continuing war and crime, while economic hardship will strengthen demagogues in exploiting ethnic rivalries and political tensions, thereby undermining peace itself (Addison, 2003).

To underscore the importance of embedding economic reforms in a broad-based economic and political agenda, consider the debate on the recent Sudanese post-conflict Poverty Reduction Strategy ${ }^{13}$, which attempts to achieve the two overarching goals of consolidating peace and reducing the risks of future wars, as well as making a lasting impact on poverty and make progress on other Millennium Development Goals (Elbadawi, 2006). Because of the complexity of the political landscape precipitated by the war, as well as the awareness generated by it, there is a consensus in Sudan that achievement of widely shared growth is an important development target, for addressing accumulated historical horizontal inequities along regional, ethnic, and gender lines. The concept of "widely shared growth" is articulated in the strategy through an explicit identification of the various types of political and economic exclusions as a source of poverty, deprivation, and conflict. Moreover, the strategy also recognizes that the achievement of widely shared growth would require political accountability and good economic governance, especially with regard to management of oil resources and aid

${ }^{13}$ Adopted by the Sudan's Government of National Unity following the peace agreement last year, which ended Africa's longest civil war. 
effectiveness. In turn, political accountability and prudent economic management must be underpinned by a social-economic contract, anchored by broad-based political participation and support from the international development community.

Figure 2 depicts the allocation of aid across different sectors during the post-conflict cycle. The distribution of aid shows that aid allocated to infrastructure tends to dominate during the pre-peace period and remains significant in post-conflict. Social sectors (i.e. education, health, water and sanitation) normally receive large amounts of aid in all three post-conflict periods and receive much more than all other sectors during PostConf1 and PostConf2. In the two latter periods, the productive sector accounts for over $10 \%$ of total aid, followed by budget support and government and institutions. Therefore aid composition reflects broadly post-conflict priorities, especially with regard to prioritizing social and infrastructure sectors.

While post-conflict economies are usually highly aid-dependent, the vast majority did not experience major RER appreciation after the start of peace - as will be illustrated for selective country cases below. If anything, conflict countries actually experienced long spells of RER depreciation, despite surging aid flows. This may reflect prima facie evidence that Dutch disease is not widespread in post-conflict experiences - but this tentative conclusion based on non-conditional observation of post-conflict RER behavior will be revisited in the next section when we analyze the RER behavior in a multivariate context, identifying the magnitude and determinants of RER misalignment.

Table 1 reports evidence on correlations between the RER, ODA, and the terms of trade (TOT) for each of the post-conflict countries in our sample. ODA and the RER are either not significantly correlated or negatively correlated in 30 of our 36 countries. The failure of the RER to appreciate with aid may be explained by the omission of other RER fundamentals, like the TOT. ${ }^{14}$ However, perhaps due to accelerated economic diversification experienced by these economies as agents disengage from their subsistence hedging strategies ${ }^{15}$, most countries did not experience significant TOT losses after attaining peace ${ }^{16}$. Hence there is no systematic evidence of a significant correlation between TOT and aid. Moreover, TOT and RER are positively correlated only in less than half of our sample of post-conflict countries.

Now we focus in more detail on the experiences of seven conflict countries: Burundi, El Salvador, Ethiopia, Mozambique, Nicaragua, Rwanda, and Uganda. Figure 3 exhibits the evolution of the share of ODA inflows to GDP, the TOT, and the RER before and after the start of peace. We start by describing the country dynamics of aid over the conflict cycle. In Burundi and Ethiopia aid flows started at high levels during PeaceOnset but

\footnotetext{
${ }^{14}$ TOT deterioration is empirically often associated with a depreciating RER although theoretically the relation between TOT and RER is ambiguous (Gavin, 1990).

${ }^{15}$ Institutions for contract enforcement break down during civil war, pushing people to engage mostly in subsistence activities, avoiding transaction-intensive activities, including exports. As the latter institutions are restored following the end of conflicts, the post-conflict economy starts to diversify again (Collier, 1999).

${ }^{16}$ In our sample, there was no significant long term trend in the TOT for 31 out of 35 countries during the ten years of post-conflict.
} 
reached their peak during PostConfl2 and PostConfl1, respectively. On the other hand, ODA peaked right from the start of peace in Mozambique, Nicaragua, Rwanda, El Salvador, and Uganda. For the first three countries, ODA was unusually large right from the PeaceOnset period, and even after precipitously declining over the rest of the postconflict cycle, it remained at high levels, close to $20 \%$ of GDP.

In the case of Uganda, donors entered gradually and tended to stay as the peace was consolidating; with initial ODA flows averaging a high of $24 \%$ of GDP at PeaceOnset, then decelerating to about $10 \%$ by the fourth year before experiencing a modest surge thereafter to reach $14 \%$ by the tenth year of peace. Finally, El Salvador provides an example of a post-conflict country that was relatively less aid-dependent, where ODA flows peaked at $6 \%$ of GDP at PeaceOnset but fell to 2\% during PostConf2. However, El Salvador is also one of the highest private remittance-receiving countries. Salvadoran worker remittances were already very high at PeaceOnset and grew to $14 \%$ of GDP at the end of PostConf2.

This unconditional country evidence depicted in Figure 3 suggests mixed evidence on Dutch disease in response to the important surge in ODA flows. In the case of Burundi, Rwanda, Uganda, and, especially, Ethiopia, there is no clear association between aid flows and RER appreciation. On the other hand, Nicaragua, El Salvador and, to a lesser extent, Mozambique, represent cases of high ODA and appreciating RERs.

Further descriptive evidence on performance measures related to the spending/saving pattern of aid of the seven countries is summarized in Table 2. The data confirms that all seven countries were recipients of large ODA flows (and of worker remittances in the case of El Salvador) during their 1990s post-conflict experiences. However, macroeconomic management of their aid surges appears to be shaped by their varied initial conditions and development strategies.

Ethiopia and El Salvador started peace with high domestic debt ratios. Their governments used part of their aid in reducing public debt levels, reflected in their declining domestic debt ratios. This helped in stabilizing their economies. Ethiopia was not only concerned about public debt but also about its RER competitiveness. This led to large reserve accumulation, supporting Ethiopia's significant RER depreciation during post-conflict. Although El Salvador reduced its debt ratio significantly, a significant part of aid (and private remittances) was used to finance domestic spending, leading to significant RER appreciation.

Burundi and Rwanda were also concerned with stabilizing their domestic debt but were also concerned about RER competitiveness. Hence both countries used part of their aid to repay public debt and finance modest reserve accumulation to preclude large RER appreciation. Like Ethiopia and El Salvador, the two latter countries refrained from excessive inflation financing.

Finally, Mozambique, Nicaragua, and Uganda used part of their aid in replenishing reserves to preventing large RER appreciation. Mozambique and Nicaragua resorted to 
inflation financing, with annual reserve money growth of $19 \%$, leading to higher inflation. However, in the case of Uganda, where reserve money grew by an annual $14 \%$, inflation was held low.

The assessment of macroeconomic outcomes of aid in the seven country experiences suggests that post-conflict countries see aid as an important source for both financing post-conflict spending needs and strengthening public-sector financial positions by saving part of aid inflows. The latter takes the form of reducing public debt and/or hoarding international reserves, which are ways to prevent larger RER appreciation. Therefore it does not come as surprise that the evidence on the simple association between aid and RER appreciation is very mixed in this sub-sample. Most post-conflict aid-recipient countries appear to have exercised the option of not fully absorbing or spending aid. All this suggests the absence of large-scale Dutch disease during the postconflict cycle. However, we will revisit this preliminary conclusion based on simple correlations and unconditional analysis, by focusing next on the behavior of the RER and the existence of RER misalignment, and its response to aid surges during post-conflict transitions, in a multivariate framework.

\section{Real Exchange Rate Misalignment during the Conflict Cycle}

The concept of RER equilibrium most commonly used in the literature is based on a single-equation reduced-form "behavioral" model of the RER that attempts to account for current-account flow variables as well as factors influencing longer-run stock equilibrium. ${ }^{17}$ The underlining notion of RER equilibrium in this approach is essentially intertemporal, as the path of the equilibrium RER is assumed to be influenced not only by the current value of the fundamentals, but also by anticipations regarding the future evolution of these variables. ${ }^{18}$

Drawing from the general empirical literature on RER behavior, and in particular from Elbadawi and Soto (2005), we will specify and estimate an empirical model for the RER. Elbadawi and Soto develop a general equilibrium model for a small three-sector open economy (with exportable, importable, and non-tradable goods) and a representative household that chooses consumption and leisure so as to maximize its welfare. The latter is adjusted for the unemployment rate that may or may not be consistent with nonclearing labor market conditions (i.e. unemployment may be higher than the NAIRU). Moreover, the specification of the household and government budget constraints account for bond holdings and fiscal transfers, which allows for explicit derivation of portfolio

\footnotetext{
${ }^{17}$ See for example, Clark and MacDonald (1999), Elbadawi (1994), Elbadawi and Soto (1997a,b), Baffes, and Elbadawi and O'Connell (1999).

${ }^{18}$ For this concept of equilibrium RER see Edwards (1989) and Elbadawi (1994). An alternative concept is the Fundamental Equilibrium Exchange Rate (FEER), which is the RER path required to achieve simultaneous internal and external balance by some date in the medium-term future and maintain balance thereafter (Williamson, 1994). Internal balance is defined by domestic and foreign output levels consistent with non-accelerating inflation-rate unemployment, while external balance is given by the sustainable net flow of resources between countries, provided that internal balance is maintained. Therefore the FEER concept corresponds to a normative notion of the equilibrium RER.
} 
and stock equilibrium variables as determinants of the RER equilibrium. Therefore this model accounts for standard RER fundamentals (such as TOT, productivity differentials, trade openness, and government consumption) as well as other RER determinants that are not frequently considered by the literature. The latter include a model-consistent measure of sustainable imports, consistent with the restriction that net foreign assets should be zero in the long run (the no Ponzi-game condition), i.e., that the current account should be zero in present-value terms. ${ }^{19}$ Another non-conventional RER fundamental included in this model is taxes on non-traded goods, which enters the government budget constraint. This is because the model assumes that the government collects taxes not just from traded goods, as in the conventional RER literature, but also from the consumption of nontraded goods and of inflation.

This model predicts the equilibrium RER to be more appreciated when production in the traded-goods sector is relatively more efficient than in the non-traded sector. Higher TOT (especially if associated to higher real prices for exports) and higher government expenditure on non-traded goods (such as government consumption) lead to equilibrium RER appreciation. On the other hand, a more open trade regime requires a more depreciated equilibrium RER. Regarding the non-traditional RER fundamentals, the model predicts that higher taxes on non-traded goods leads to a more appreciated equilibrium RER, provided that the weight of traded goods in domestic consumption is lower than the labor intensity in the non-traded sector. This is because such taxes would lower supply of, more than they would lower the demand for, non-traded goods. Finally, a higher level of sustainable imports is predicted to lead to more appreciated RER.

While the Elbadawi and Soto model addresses some of the major critiques of the empirical real exchange rate literature, most notably the lack of an explicit and modelconsistent concept of a sustainable current-account balance, the estimation of the latter is highly demanding in terms of time-series data. This is a major constraint for our focus on low-income aid-dependent countries. Moreover, while their framework - based on a sustainable current-account balance - is useful for undertaking a theoretically-consistent analysis of the determinants of the long-run equilibrium RER, it abstracts from critical medium-term policy issues, associated with private net capital flows and foreign reserve accumulation. Consequently, we estimate a version of their model, consistent with a medium-term concept of the sustainable current account, by including foreign aid net of changes in foreign reserves held by the monetary authority, net foreign income from abroad, and net private capital inflows. A sustainable increase in any of the three latter components would lead to an equilibrium RER appreciation.

\footnotetext{
19 This is given by an expression of future discounted export proceeds minus debt service plus transfers (e.g. aid and remittances). The failure to explicitly account for this feature as an endogenous outcome of RER models is one of the most fundamental problems of the empirical RER literature discussed by Edwards and Savastano (1999).
} 
Therefore, we specify the following equation for the RER:

(1)

$$
\begin{aligned}
\log \left(\text { RER }_{i t}\right)= & \beta_{0 i}+\beta_{1} \log (\text { TOT })+\beta_{2} \log (P R O D)_{i t}+\beta_{3} O P E N_{i t}+\beta_{4} \log (G O V)_{i t} \\
& +\beta_{5} \log (T A X)_{i t}+\beta_{6} A I D_{i t}+\beta_{7} N F I_{i t}+\beta_{8} N P C_{i t}+\varepsilon_{i t}
\end{aligned}
$$

where subscripts $i$ and $t$ represent country and time indexes, respectively; TOT is the terms of trade; $P R O D$ stands for productivity proxied by the ratio of income per capita in country $i$ relative to the OECD average; OPEN represents trade openness computed as the residual from a regression of trade as a share of GDP on geography variables (e.g. land area of a country, landlockedness) ${ }^{20} ; G O V$ is the share of government consumption on GDP; TAX corresponds to taxes on non-traded goods; AID denotes ODA as a share of GDP net of changes in foreign exchange reserves; $N F I$ denotes net foreign income as a share of GDP; and NPC corresponds to net private capital inflows as a share of GDP. Finally, $\beta_{0 i}$ and $\varepsilon_{i t}$ are country-specific intercepts and a disturbance term, respectively.

We estimate equation (1) for a world sample of annual data for 83 countries (including 36 post-conflict countries) for the 1980-2004 period. Data definitions and sources are summarized in Appendix B. Table 3 reports the results for the pooled mean group model (PMG), as well as results based on mean group (MG) and dynamic fixed-effects (DFE) estimation methods ${ }^{21}$. The PMG estimator can be seen as a restricted-model estimator, in the sense that it imposes the restriction that all countries share the long-run coefficients, against the more general model that assumes that economies differ in their short and long-run parameters. However, the PMG estimator is more general than the individualeffects panel-data model, which assumes that all parameters are constant across countries. This restriction can be tested by performing Hausman tests. The null hypothesis of equality of coefficients can be rejected at the $1 \%$ level, except for productivity and foreign aid (net of international reserves), for which the null hypothesis can be rejected at the $10 \%$ level. This evidence favors the PMG model against the MG estimator.

The PMG results show that all parameters are highly significant (exceeding 99\% confidence levels) and display expected signs according to theory. The PMG results dominate those based on the alternative estimators, consistent with the results reported by Elbadawi and Soto (2005) and comparable to the results found in the existing literature. ${ }^{22}$ The semi-elasticities of net foreign income and foreign aid (net of reserve accumulation) are equal to 0.004 and 0.002 , respectively. The estimated elasticity for the tax on nontradables is substantial - i.e. 2.3 .

\footnotetext{
${ }^{20}$ This residual measure of openness nets out natural openness and therefore is a better proxy for policyoriented openness.

${ }^{21}$ The inclusion of the capital inflows variable is problematic, as it significantly worsens the results for the DFE model, which is used as a benchmark for the PMG model. Therefore we dropped it from the model, partly also to reduce the dimensionality of the PMG and increase regression precision.

${ }^{22}$ Comparable findings in the literature, include Chinn (1997) for productivity; Elbadawi and Soto (1997) and Drine and Rault (2004) for TOT; and Elbadawi and Soto (1997) and Maeso-Fernandez et al. (2002) for government consumption.
} 
Regarding the speed of adjustment and the short-term elasticities, the results in Table 3 also show that there are marked differences among estimation techniques. Unlike the other two regression methods, the results for the PMG model suggest that some fundamentals like terms of trade and productivity have highly significant short-run effects.

The most important parameter in the estimation of short-run dynamics is the coefficient of the equilibrium RER correction term, which measures the speed of adjustment of the real exchange rate to its equilibrium level. The estimated average adjustment parameter is -0.20 , which is equal to the one obtained by Edwards (1989) using a partial adjustment model for a group of 12 developing countries. The PMG coefficient estimate is, however, smaller than that obtained by the DFE model (at -0.25) and much smaller compared to the MG estimate of -0.70 . The PMG estimate is also much smaller than coefficients obtained from time-series models. This suggests that, like other panel regressions, the PMG model might understate the true level of the convergence parameter because it fails to capture short-run heterogeneity across countries. ${ }^{23}$

Using our model results and following Elbadawi, Kaltani, and Soto (2006), now we proceed to construct indexes for the equilibrium real exchange rate (ERER) and real exchange rate misalignment (rermis). The ERER index is obtained from the estimated model with the permanent components of the fundamentals (estimated with the HodrickPrescott procedure) substituted into the estimated RER equation. The permanent components of the fundamentals are characterized as sustainable levels and are therefore consistent with the concept of RER equilibrium. The ERER index is normalized (through the country-specific intercept) so that the average RER misalignment (the mean logarithmic difference between the RER and ERER for each country) is set equal to zero. This imposes the plausible identification condition that no country is allowed to be misaligned for the full estimation period. The log of the resulting normalized ERER is then subtracted from the log of the RER to obtain the rermis time-series measures for each country. ${ }^{24}$

The first four rows of Table 4 provide the median estimates of RER misalignment over the post-conflict cycle for the sample of post-conflict countries. The table also reports a breakdown of rermis into one component (labeled Fundamentals) due to the discrepancy of observed fundamentals from their-long term sustainable trends and a second component (labeled error correction) due to short-term policy or structural shocks to fundamentals. The next columns summarize the effects due to policy-oriented fundamentals and those associated with structural fundamentals, including ODA. The final column reports the separate contribution of ODA.

\footnotetext{
${ }^{23}$ However, unlike other panel regression models, the possible failure of the PMG to account for short-run country heterogeneity is likely to be because of the inadequacy of the time-series dimension of the data, since the model does not impose restrictions on short-run parameters.

${ }^{24}$ Appendix $\mathrm{C}$ contains a detailed description of the construction of these indexes using the RER equation estimates.
} 
Our rermis estimates suggest that the median post-conflict country entered peace with a mildly undervalued exchange rate observed during the 4 PrePeace years, reflected by a rermis of $-1 \%$. However after peace is started, the median post-conflict country experiences a moderate RER overvaluation of $11 \%$ during PeaceOnset and $10 \%$ during PostConf1. RER overvaluation is substantially reduced - to 4\% - during PostConf 2 .

Foreign aid does not appear to have contributed directly to RER overvaluation during the conflict cycle. The reason is straightforward. While ODA increased during the postconflict period, peaking during PeaceOnset in the median country (as documented above), the deviation of post-conflict ODA from permanent ODA flows was not very large. However, ODA is likely to have contributed to the large error-correction component, which comes to about 11\% during PeaceOnset and PostConf1 and 6\% during PostConf2.

Now we turn to rermis and its decomposition in each of the seven individual post-conflict countries that we focused on in the preceding section. The lower part of Table 4 reports estimates of average RER misalignment and its breakdown, separately for each country and conflict sub-period, comparable to those reported above for the median post-conflict country. The pattern of rermis varies strongly from country to country. Burundi and Uganda experienced RER over-appreciation during most of the pre and post-peace subperiods. By contrast, Ethiopia was substantially overvalued after the war ended but achieved a major correction in the PostConfll period and brought the RER close to equilibrium in the PostConf2 period. The remaining countries - El Salvador, Mozambique, Nicaragua, and Rwanda - shifted from significant RER undervaluation in PrePeace to significant RER overvaluation at subsequent periods. Among the latter countries, RER overvaluation ranges from $6 \%$ in Nicaragua to a very large $41 \%$ in El Salvador during PostConf2.

High aid flows did not contribute substantially to rermis in any of the seven individual countries. (The exception is aid in Mozambique during PeaceOnset, but during the two subsequent sub-periods the country experienced substantial undervaluation). This finding is broadly consistent with the evidence of a miniscule contribution of large aid flows in the median post-conflict country during the post-conflict cycle.

Summing up, there is evidence of moderate RER overvaluation observed in the median post-conflict experience, particularly during PeaceOnset and PostConfl sub-periods. Aid, however, does not contribute significantly and directly to RER overvaluation in the average aid-receiving country and in the seven country cases that we reviewed in more detail. The reason is that aid, while peaking during PeaceOnset, does not deviate massively from its permanent values during post-conflict periods.

\section{Catch-up Growth in Post-Conflict}

A general result from the recent cross-country econometric research on aid effectiveness

is that aid does not generally influence economic performance, most notably economic 
growth. However, when aid is delivered to countries that feature a good policy environment, it may increase growth but its effect is subject to diminishing returns (e.g. World Bank, 1998; Burnside and Dollar, 2000). ${ }^{25}$ The issue of aid effectiveness has also been studied in the context of post-conflict transitions, where relative to normal peaceful environments, aid was found to be super-effective (e.g. Collier and Hoeffler, 2002). This is because civil wars are characterized by an immediate and substantial decline of output, and when they last long enough they can also destroy the physical, human, and social capital of affected countries. ${ }^{26}$ Therefore economies tend to experience drastic underperformance during war years, which opens up a large potential for post-conflict catch-up growth, mainly driven by aid-financed reconstruction and recovery efforts.

Unlike Collier and Hoeffler, who emphasize the role of the overall institutional and policy environment in enhancing the absorptive capacity of aid at various post-conflict periods, we control for the direct growth effects of institutions and other conventional growth fundamentals but emphasize the growth and aid-effectiveness consequences of RER misalignment.

A strand of the empirical growth literature that accounts for the impact of RER misalignment finds robust negative association between RER overvaluation and growth. While moderate undervaluation might support growth, extreme undervaluation also leads to less growth (Razin and Collins 1997, Aguirre and Calderon, 2005). Another finding of this literature is that the growth impact of RER overvaluation and RER volatility is contingent on the level of financial development; they generally reduce growth in countries with low levels of financial development while having no significant effect in financially advanced economies (Aghion et al., 2006).

Next we specify and estimate an empirical growth model that nests the four latter strands of the growth literature: conflict periods, aid, RER competitiveness, and financial development, as well as their possible interactions. Controlling for conventional growth determinants that are robustly identified in the empirical cross-country growth literature, we address the following issues that have not been addressed in aid and post-conflict transition literature yet. First, which are the separate effects of peace and post-conflict periods, aid, RER misalignment, and financial development, on growth? Second, does aid reduce or augment the impact of RER misalignment on growth? Third, does aid increase the contribution of post-conflict peace to growth? Finally, is the growth loss from RER misalignment ameliorated by financial development?

To address these questions, we specify and estimate the following growth model:

\footnotetext{
25 More recent work by Radelet, Clements and Bhavnani (2003) argues for the need to disaggregate aid by its purpose in order to accurately assess its impact on economic growth. They find that the growth impact of disaggregated aid flows is larger than previously found (although it presents diminishing returns) regardless of recipient countries' policy environment. This research direction path, although appealing, goes beyond the scope of our current work.

${ }^{26}$ For example, Collier (1999) estimates a growth model that accounts for duration and legacy of civil wars. He finds that, relative to the counterfactual of peace, the marginal effect of a civil war causes per capita output to decline by about $2 \%$ per annum during wars.
} 
(2)

$$
\begin{aligned}
y_{i t}= & \beta_{0} A_{i t}+\beta_{1} A^{2}{ }_{i t}+\beta_{2} \text { RERMIS }_{i t}+\beta_{3} P C+\beta_{4} F D_{i t}+\beta_{5} A_{i t} * R E R M I S_{i t} \\
& +\beta_{6} A_{i, t} * P C+\beta_{7} * R E R M I S_{i, t} * F D_{i, t}+\beta_{8}{ }^{\prime} C V_{i, t}+\mu_{t}+\eta_{i}+\varepsilon_{i, t}
\end{aligned}
$$

where $i$ and $t$ are country and time indexes, respectively; $y$ is per-capita GDP growth; $A$ is ODA as a share of GDP, ${ }^{27}$ RERMIS is RER misalignment, $P C$ is a vector of three post-conflict period variables (Peace Onset takes the value of 1 if the year of peace falls within that period, Post-conflict 1 takes the value of 1 if the war ended in the previous period, and Post-conflict 2 takes the value of 1 if the war ended two periods before); $F D$ is a measure of financial development, $C V$ is a set of standard control variables that are robustly associated with cross-country growth (initial per capita GDP, initial GDP cyclical component, inflation, government expenditure as a share of GDP, human capital investment, a rule of law index, and a measure of trade openness); and $\mu_{t}$ and $\eta_{i}$ are time and country fixed-effects, respectively.

Policy fundamentals are likely to be jointly determined with growth as well as responsive to future anticipated growth performance. Therefore, to properly account for endogeneity and country-specific unobserved characteristics, we use the Generalized Method of Moments (GMM) system dynamic panel estimation method. We apply it to a world data panel of 78 countries, comprised by post-conflict and other developing economies, as well as industrial countries, for 5-year non-overlapping averages spanning the period 1970 until 2004. The system GMM (developed in Arellano and Bover, 1995 and Blundell and Bond, 1997) implemented here, uses lagged values of the dependent and independent variables as instrument (called 'internal instruments') and combines regressions in differences with the regressions in levels to better address the issue of weak instrumentation often attributed to the older, difference estimator. Under the assumed moment conditions, the system GMM accounts for the combined problems of endogeneity and unobserved country effects. The consistency of the GMM system estimator is assessed by two specification tests. The Sargan test of overidentifying restrictions tests the overall validity of the instruments. Failure to reject the null hypothesis gives support to the model. The second test examines the null hypothesis that the error term is not serially correlated. Again, failure to reject the null hypothesis gives support to the model. Rejecting the null hypothesis would imply that the instruments are inappropriate and would call for higher-order lags of the variables to be used as instruments.

The regression results along with the Sargan and the serial-correlation tests are reported in Table 5. The first column reports the results of estimating equation (2) excluding the interaction terms, the second column reports the results using the full specification, and

\footnotetext{
${ }^{27}$ The values for official development assistance are set equal to zero for the OECD countries. Aid is measured at the beginning of each period as it is believed to be more relevant for current growth because the overwhelming evidence (reviewed in the previous section) seems to suggest that recipient countries tend to absorb and/or spend aid with some time lag. Beginning of period aid is also likely to be exogenous because aid is partially responsive to recipient countries' past economic performance, including past growth.
} 
column 3 reports a more parsimonious regression which excludes non-significant variables. In general, all standard growth fundamentals have the expected sign and are statistically significant. Moreover, both the Sargan and the serial-correlation tests validate our specification. $^{28}$

The results reported in column of Table 5 show that aid is positively but nonmonotonically associated with growth. RER misalignment has a negative effect on growth. The baseline regression results also suggest that there is evidence of a direct peace dividend in the Post-conflict 1 and 2 periods but not in the immediate post-conflict period of Peace-onset. The marginal effects of Post-conflict 1 and 2 periods on growth are large $-1.6 \%$ and $2.1 \%$, respectively. The measure of financial development is not statistically significant in this specification.

When we allow for interaction terms, the direct effect of RER misalignment strengthens, while the direct effects of post-conflict variables become insignificant (column 2 of Table 5). As expected, the interaction between RER misalignment and aid has a negative and significant effect on growth, while aid has an additional positive marginal effect on growth in the Post-conflict 1 and 2 periods. Under this specification, we find that financial development has a positive and significant effect on growth and, in addition, neutralizes in part the negative impact of RER misalignment.

The latter results corroborate two key results about aid effectiveness. First, aid is more effective in a good policy environment, which in our case implies avoiding RER overvaluation. Second, aid effectiveness is subject to diminishing returns. Moreover, the results also support the view that aid is super-effective in post-conflict. Finally, our findings suggest that financial development not only improves growth directly but also ameliorates the negative repercussions of RER overvaluation. The more parsimonious regression results in column 3 of Table 5 confirm the latter evidence.

We can use the results of column 3 to probe deeper into the analysis of RER misalignment on growth. From equation (2), note that the overall growth effect of a change in RER misalignment is given by the following expression:

$$
\Delta y_{i t}=\left(\beta_{2}+\beta_{5} A+\beta_{7} * F D\right) \Delta R E R M I S
$$

where $\beta_{2}$ is the direct effect of RER misalignment on growth, and $\beta_{5} A$ and $\beta_{7} F D$ are the non-linear effects of RER misalignment on growth that depend on the levels of aid and financial development. The estimated parameters suggest that the direct effect of half a standard deviation change in RER misalignment would amount to about a 5\% loss in economic growth. In addition, if aid and financial development were held at their median

\footnotetext{
${ }^{28}$ An alternative approach to identifying growth determinants can be based on regressing current per capita growth rates on lagged right-hand side variables by assuming that, aside from lagged income per capita, all other time-varying growth fundamentals are exogenous. This could be useful in minimizing the number of variables to be instrumented. However, the validity of this simpler approach hinges on a more restrictive assumption about the temporal endoegeneity of the policy and institutional growth fundamentals.
} 
values, the indirect effects of misalignment would amount to a loss of nearly $0.5 \%$ and a gain of nearly 5\%, respectively. Nevertheless, many of the post-conflict countries are highly dependent on aid and have rather shallow financial markets. In order to reflect such reality and obtain more realistic scenarios, we perform three exercises. First, we investigate the effects of RER misalignments on growth under different levels of aid dependency, and under different levels of financial development. Finally, we calculate the impact on growth of an enhanced financial sector under different levels of RER misalignment.

In the first exercise, we assume that a shock of a one standard deviation affects the RER misalignment. We assume three levels of ODA, namely at the $25^{\text {th }}, 50^{\text {th }}$, and $75^{\text {th }}$ percentiles of the distribution of ODA in the Post-conflict 1 period, and holding the level of financial development at its median value in the Post-conflict 1 period for the countries in our regression sample. Countries with low aid dependency (close to the $25^{\text {th }}$ percentile) correspond to Egypt and Thailand in recent years while high aid-dependent countries (close to the $75^{\text {th }}$ percentile) are Mali and Senegal in recent years. Figure 4 depicts the impact of such scenarios on economic growth. As evidenced by the figure, the level of aid plays an important role in the ability of RER misalignment to affect growth. A onestandard-deviation change in RER misalignment would lower growth by nearly $1 \%$ under a low-aid scenario and by $2.5 \%$ under a high-aid scenario.

Figure 4 also shows the growth impact of the same change in RER misalignment but under various levels of financial development, while holding aid at its median value in the Post-conflict 1 sample. Post-conflict countries present large heterogeneity in financial market development. A country with low financial development (at the $25^{\text {th }}$ percentile) is Guatemala in the late 1990's, while a country with high financial development is El Salvador in the same period. The simulation results show that the level of financial development mitigates some of the detrimental effects of overvaluation. Countries with highly developed financial markets face a $0.6 \%$ growth reduction as a result of larger RER misalignment, while those lagging behind in financial development could face lower growth of to $2.4 \%$. Hence financial sector reform can foster economic development directly and make growth more resilient to large RER overvaluation. Our final exercise assumes that there is a one-standard-deviation shock to financial development under three scenarios of RER misalignment (the $25^{\text {th }}, 50^{\text {th }}$, and $75^{\text {th }}$ percentile of RERMIS in the postconflict 1 period). The positive impact on growth of an enhanced financial system lies between $0.05 \%$ and $1.32 \%$, depending on the levels of RER misalignment.

Our three exercises reflect the significant impact of RER misalignment on growth, particularly in countries that benefit from high levels of ODA. Our results also show that financial sector reform is likely to play a role in preventing a significant part of the growth reduction caused by RER misalignment.

\section{Conclusions}

The evidence presented in this paper has shown that post-conflict countries receive substantial aid flows after the start of peace. An aid-recipient government has to decide 
how much of its aid to spend and to save, which fraction of spending should fall on traded and non-traded goods, and which part of saving should be used to build-up foreign-currency and domestic-currency public-sector net assets. The latter decisions are shaped by domestic economic and political factors, as well as by aid conditionality, which depend on country and conflict-specific conditions.

The flow of aid to post-conflict countries appears not to be well synchronized with country capacity to absorb aid. While post-conflict countries capacity to absorb aid (i.e., the quality of their policies and institutions) is built up only gradually after peace onset, the evidence suggests that aid tends to peak immediately after peace is attained and decline thereafter. This suggests that the timing of aid is often not optimal; too much aid is provided too early and is reduced prematurely. However, aid composition broadly reflects post-conflict priorities, with large parts of aid financing social expenditure and infrastructure investment.

The evidence shows that many post-conflict countries reduced public debt and increased international reserves substantially. The latter forms of saving aid contributed to avoid significant RER appreciation in post-conflict countries. The long-term (1970-2000) correlation between aid and the RER is either non-significant or negative in 29 out of 32 conflict countries. All this partial evidence suggests little prima-facie evidence of Dutch disease during post-conflict surges - but more systematic multivariate evidence is required to assess the sensitivity of RERs to aid flows.

We have provided the latter evidence from an error-correction model for the RER, based on conventional and non-conventional determinants, including foreign aid. The empirical results - based on a world sample of 1980-2004 annual data for 83 countries - point out that aid has significant, but small, long-term effects on the RER, controlling for a host of policy and structural fundamentals. We used the latter results to compute RER misalignment (rermis), breaking it down according to the contribution of deviations of fundamentals (including aid) from their long-term trend values and of short-term dynamics. Our results point out that the median post-conflict country suffered from moderate RER overvaluation after the start of peace, during PeaceOnset and PostConf1 sub-periods. However, rermis observed during post-conflict periods cannot be traced down to the aid flows that peaked during PeaceOnset during this sub-period. Therefore large aid flows have not been a major factor in the moderate RER overvaluation observed in post-conflict experiences.

The empirical evidence on growth in the world presented in this paper reveals new findings about the pattern of catch-up growth during post-conflicts and the role of some key growth determinants of post-conflict growth. Aid is an important determinant of growth. Prima facie, there is evidence of a large peace bonus earned in years 2-9 after the start of peace. However, this evidence on the direct linear effects of peace on growth fades away when considering the interaction between foreign aid and post-conflict periods, which shows that it is the latter interaction that matters significantly for growth. Hence peace per se does not improve growth - it only affects growth when combined with large aid. 
In the world sample, RER misalignment has a large, negative, linear effect on growth. As post-conflict periods have been characterized by moderate RER overvaluation, the latter has reduced post-conflict growth. Moreover, aid and RER overvaluation have a combined negative growth effect. However, the negative growth effects of RER overvaluation decline to a large extent with financial development. Hence financial reform has an additional bonus not much considered before: it might neutralize a significant part of the negative growth effect of RER misalignment.

\section{Some Policy Implications}

Our results lead to the following inferences for the management of aid and the conduct of macroeconomic and structural policies in the years following attainment of peace. Peaks of aid inflows at peace onset and shortly thereafter have been observed in many postconflict cases - an experience that donor and recipient countries should agree to avoid in the future. Spreading out aid commitments over longer future horizons has the benefit of bringing actual aid flows closer to permanent aid flows, so that spending aid will be more consistent with permanent aid resources. Moreover, as building up the quality of policies and policy institutions is a gradual process after peace onset, aid flows should increase with the latter domestic improvements in order to maximize aid effectiveness. This recommendation is based on our results on aid effectiveness: the largest growth impact of aid is during years 6-9 after the start of peace.

What should be done with aid resources? Here a fine balance has to be struck between the goal of spending aid quickly on high-priority social programs - including humanitarian aid, social sectors, and infrastructure recovery - and the objective of saving part of aid by building up public-sector net assets (accumulating foreign reserves or reducing publicsector debt). As time passes and public-sector net assets attain acceptable levels, a rising share of aid resources should be spent, in accordance with expected sustainable aid flows. This (shifting) balance should be the result of equilibrating government objectives of assistance to conflict victims and poverty reduction, and supporting macroeconomic stabilization (i.e., attaining fiscal sustainability, low inflation, and international competitiveness). However, maintaining a strong policy focus on the latter objectives without succumbing to domestic political pressures and ad hoc donor conditionality goals represents a serious challenge to post-conflict governments.

Our results on moderate RER overvaluation in post-conflict periods and its negative impact on growth lead to the following inference on policies in support of strong international competitiveness. Some policy handles that are available to post-conflict governments to avoid RER overvaluation are in the realm of fiscal policy. They point toward keeping under control overall government spending and taxation of non-traded

goods and services. Avoiding excessive government spending has the added benefit of raising short and long-term growth, both directly (shown by our results, confirming previous studies) and indirectly by reducing RER overvaluation (shown by our results). Authorities should also limit government expenditure volatility and keeping the primary 
non-aid deficit within limits consistent with expected sustainable aid flows. This should contribute to ensure that the RER follows a path that is consistent with equilibrium behavior. Other fiscal measures in support of international competitiveness are related to the composition of government expenditure. For example, government programs in support of agriculture - a key traded-goods sector in many poor post-conflict economies - such as improving rural infrastructure, credit access, and marketing, will contribute to competitiveness and enhance economic diversification.

In the realm of structural policies, our results suggest that financial development and deepening - including banking and capital-market development - has a direct positive effect on long-term growth and an additional positive growth bonus by reducing the adverse growth impact of RER overvaluation. Therefore the promotion of financial development and deepening should be high on the priority of post-conflict government policies. This would include strengthening domestic banking (by adopting banking laws based on prudential regulation and supervision at high international standards) and supporting development of domestic capital markets.

If post-conflict central banks adopt more flexible exchange-rate regimes, moving away from pegs or intermediate regimes of limited flexibility, this may strengthen monetary policy but may also increase short and medium-term exchange-rate volatility. In order to minimize the costs of ensuing RER uncertainty for domestic producers, governments and central banks should promote market development of foreign-exchange hedging instruments (like futures and other options) through adoption of appropriate financial regulation and possibly engaging initially in the supply of the latter financial instruments in support of their development.

Finally, our results show that trade openness contributes significantly to a more depreciated exchange rate and raises growth through two channels: directly and indirectly by reducing the likelihood of RER misalignment. Therefore trade reform should also be high on the structural policy agenda of post-conflict governments. ${ }^{29}$

\section{References}

Addison, T (ed.) (2003). From Conflict to Recovery in Africa. Oxford University Press for UNU/WIDER: Oxford.

Aghion, P., P. Bacchetta, R. Ranciere, and K. Rogoff (2006). "Exchange Rate Volatility and Productivity Growth: The Role of Financial Development," Harvard University, manuscript.

Aguirre, A. and C. Calderón (2005). " Real Exchange Rate Misalignments and Economic Performance," Central Bank of Chile Working Paper.

${ }^{29}$ To illustrate the economic significance of fiscal and structural reforms for raising international competitiveness, we refer to the recent results by Elbadwi and Soto (2005), who find that a combination of expenditure restructuring, reduction of taxes on non-tradables and trade refom could lead to an equilibrium RER depreciation ranging from 30 to $40 \%$. 
Aiyar, S., A. Berg, and M. Hussain (2005). "The Macroeconomic Challenge of More Aid," Finance and Development, vol. 42 (3), IMF.

Arellano, M., and O. Bover (1995). "Another Look at the Instrumental-Variable Estimation of Error-Components Models." Journal of Econometrics 68(1): 29-52.

Baffes, J., I..A. Elbadawi, and S.A. O'Connell. (1999). "Single-Equation Estimation of the Equilibrium Real Exchange Rate." in Exchange Rates Misalignment: Concepts and Measurement for Developing Countries. L. Hinkle and P. Montiel (eds). World Bank, Policy Research Department, Washington, DC.

Barder, O. (2006). "Are the planned increases in aid too much of a good thing?," Working Papers 90, Center for Global Development.

Bayoumi, T., P. Clark, S. Symansky, and M. Taylor (1994). "The Robustness of Equilibrium Exchange Rate Calculations to Alternative Assumptions and Methodologies," in J. Williamson (ed.), Estimating Equilibrium Exchange Rates, Washington, D.C.: Institute for International Economics.

Blundell, R. and S. Bond (1997). "Initial Conditions and Moment Restrictions in Dynamic Panel Data Models". University College London Discussion Papers in Economics: 97/07, July.

Burnside, C. and D. Dollar (2000). "Aid, Policies, and Growth.” American Economic Review, Vol. 90(4): 847.

Chinn, M. (1997): "Sectoral Productivity, Government Spending, and Real Exchange Rates: Empirical Evidence for OECD countries." NBER Working Paper Series 6017.

Clark, P. and R. MacDonald (1999)., "Exchange Rates and Economic Fundamentals: A Methodological Comparison of BEERs and FEERs." in J. Stein and R. MacDonald

Clements, M., S. Radelet and R. Bhavnani (2004). "Counting Chickens when they Hatch: The Short-Term Effect of Aid on Growth," Center for Global Development Working Paper No. 44.

Collier, P. and D. Dollar (2002). "Aid Allocation and Poverty Reduction." European Economic Review. Vol. 46(8): 1475-1500.

Collier, P and A. Hoeffler (2002). "Aid, Policy, and Growth in Post-conflict Societies." Policy Research Paper Series, The World Bank: 2902.

Collier, Paul (1999), "On the Economics Consequences of Civil War." Oxford Economic Papers, vol. 51: 168-83. 
Cottani, J. D., Cavallo and S. Kahn (1990). "Real Exchange Rate Behavior and Economic Performance in LDCs.” Economic Development and Cultural Change. 39(1): 61-76.

Drine, I. and C. Rault (2004): “On the Long-run Determinants of Real Exchange Rates for Developing Countries: Evidence from Africa, Latin America and Asia", mimeo, Sorbonne University.

Dufrenot, G. and E. Yehoue (2005). "Real Exchange Rate Misalignment: A Panel CoIntegration and Common Factor Analysis," IMF Working Paper WP/05/164.

Easterly, W. and R. Levine (1997). "Africa's growth tragedy: policies and ethnic divisions," Quarterly Journal of Economics. 112: 1203-1250.

Edwards, S. and M. Savastano (1999). "Exchange Rates in Emerging Economies: What Do We Know? What Do We Need to Know?" National Bureau of Economic Research Working Paper No. 7228.

Edwards, Sebastian (1989). Real Exchange Rate, Devaluation and Adjustment: Exchange Rate Policy in Developing Countries. Cambridge, MA: MIT Press.

Elbadawi and Schmidt-Hebbel (2005)

Elbadawi, I. (1994). "Estimating Long-Run Equilibrium Real Exchange Rates", in J. Williamson (ed.), Estimating Equilibrium Exchange Rates, Washington, D.C.: Institute for International Economics, 1994.

Elbadawi, I. (1999). "External Aid: Help of Hindrance to Export Orientation in Africa?" Development Research Group and Africa Region, the World Bank. Journal of African Economies. 8 (4): 578-616.

Elbadawi, Ibrahim (2006). "An MDG-based Strategy for Re-building the Post-conflict Sudanese Economy." (Forthcoming), in Leonard Binder (editor). Rebuilding Devastated Economies of the Middle East. Palgrave Macmillan.

Elbadawi, I., L. Kaltani, and K. Schmidt-Hebbel (2006). "Post-Conflict Aid, Real Exchange-Rate Adjustment, and Catch-Up Growth", World Bank Working Paper, forthcoming.

Elbadawi, I., L. Kaltani, and R. Soto (2006). "Real Exchange Rate Misalignment in SSA: How Serious, How Dangerous,” Unpublished World Bank Memo. (forthcoming).

Elbadawi, I. (2002). "Real Exchange Rate Policy and Non-traditional Exports in Developing Countries," in G.K. Helleiner (ed.), Non-Traditional Export Promotion in Africa: Experiences and Issues, Palgrave, New York.

Elbadawi, I. and R. Soto (1997a). "Capital Flows and Long-Term Equilibrium Real Exchange Rates in Chile," Revista de Analisis Economico. (June) 12 (1): 35-62. 
Elbadawi, I. and R. Soto (1997b). "Real Exchange Rates and Macroeconomic Adjustment in Sub-Saharan Africa and Other Developing Countries," in Elbadawi and Soto (op. cit.) Journal of African Economies.

Elbadawi, I and R. Soto (2005). "Theory and Empirics of Real Exchange Rates in SubSaharan Africa and Other Developing Countries," Unpublished World Bank Memo. (November 14).

Gavin, M. (1990). "Structural Adjustment to a Terms of Trade Disturbance: The Role of Relative Prices." Journal of International Economics. Vol. 28(3-4):217-43.

Ghura, D. and T. J. Grennes (1993). "The Real Exchange Rate and Macroeconomic Performances in Sub-Saharan Africa," Journal of Development Economics. Vol. 42.

IMF (2005). "The Macroeconomics of Managing Increased Aid Inflows: Experiences of Low-Income Countries and Policy Implications" Available at http://www.imf.org/external/np/pp/eng/2005/080805a.pdf.

Kaminsky, G., and C.M. Reinhart (1999). "The Twin Crises: The Causes of Banking and Balance of Payments Problems. American Economic Review. 89 (3): 473-500.

Kang, S., and J. Meernik (2004). 'Determinants of Post-Conflict Economic Assistance'. Journal of Peace Research, 41 (2): 149-66.

Krugman, P. 1987. "The Narrow Moving Band, the Dutch Disease, and the Competitive Consequences of Mrs. Thatcher: Notes on Trade in the Presence of Dynamic Scale Economies." Journal of Development Economics, 27: 41-55

Maeso-Fernandez, F., C. Osbat, B. Schnatz (2002). "Towards the Estimation of Equilibrium Exchange Rates for CEE Acceding Countries: Methodological Issues and a Panel Cointegration Perspective.” European Central Bank, Working Paper Series: 353.

Mengistae, Taye, and Catherine Pattillo (2004). "Export Orientation and Productivity in Sub-Saharan Africa," International Monetary Fund. IMF Staff Papers, 51 (2): 327.

Merrill Lynch (1998). "A Global Currency and Interest Rate Outlook."

Nabli, K. Mustapha, and Marie-Ange Veganzones-Varoudakis, (2002). "Exchange Rate Regime and Competitiveness of Manufactured Exports: The Case of MENA Countries," World Bank, Washington DC, Centre National de la Recherche Scientifique, Centre d'Etudes et de Recherches sur le Developpement International, France, (May).

Pesaran, H.; Y. Shin and R. Smith (1999): "Pooled Mean Group Estimation of Dynamic Heterogeneous Panels", Journal of the American Statistical Association, 94:621-634.

Radelet, Clements and Bhavnani (2003). 
PRIO (2005). The Armed Conflicts Database, version 3. http://new.prio.no/CSCWDatasets/Data-on-Armed-Conflict/UppsalaPRIO-Armed-Conflicts-Dataset/Armed-

Conflicts-Old-Versions/

Razin, O., and S. M. Collins (1997). "Real Exchange Rate Misaligments and Growth," National Bureau of Economic Research Working Paper \#6174. (September): Cambridge, MA.

Sachs, J. D. and A. M. Warner (1999), Sources of Slow Growth in African Economies, Journal of African Economies, 6(3): 335-76

Sachs, J. D. and A. M. Warner (1995) "Natural Resource Abundance and Economic Growth," NBER Working Paper No. 5398, Cambridge, MA.

Sambanis (2004), "List of Civil Wars: 1945-1992", available at http://pantheon.yale.edu/ ns237/index/research.html\#Data.

Schwartz, J., P. Halkyard, S. Smith (2006) "Post-conflict Infrastructure - trends in aid and investment flows." The World Bank. Private Sector Development VP. News Letter (note no. 305).

Schwartz, Jordan, P. Halkyard, S. Smith (2006) "Post-conflict Infrastructure - trends in aid and investment flows." The World Bank. Private Sector Development VP. News Letter (note no. 305).

Spatafora, N. and A. Warner. 1999. "Macroeconomic and Sectoral Effects of Terms of Trade Shocks: The Experience of the Oil-Exporting Developing Countries." IMF Working Paper WP134.

Wijnbergen, van S. (1984) “The Dutch Disease: A Disease after all?” Economic Journal, 94: 41-55.

Wijnbergen, van S. (1986). "Aid, Export Promotion and the Real Exchange Rate: an African Dilemma." Mimeo, The World Bank.

Weiss, M. (2004). "World Bank Post-conflict Aid: Oversight Issues for Congress.” CRS Report for Congress. Congressional Rsearch Service, the Library of Congress. Order Code RS21819.

Williamson J. (1994). "Estimates of FEERs," Estimating Equilibrium Exchange Rates. Williamson (ed.) Washington DC: Institute for International Economics.

World Bank (1998). Assessing Aid. New York: Oxford University Press.

World Bank Database, World Development Indicator (WDI 2006). 
Wren-Lewis, S. and R. Driver (1997). "Real Exchange Rates for the Year 2000," (Washington: Institute for International Economics), unpublished. 


\section{List of Figures and Tables}

Table 1 Long-run Correlations of Aid, Real Exchange Rates (RER), and Terms of Trade (TOT) in Post-Conflict Countries

Table 2 Performance Measures of Selected Post- Conflict Countries

Table 3 Long and Short-Term Determinants of the Real Exchange Rate in the World

Table 4 Real Exchange Rate Misalignment (rermis) and its Decomposition in PostConflict Countries (Averages per conflict and post-conflict sub-periods)

Table 5 Economic Growth and the Role of Aid, RER Misalignment, and Financial Development in the World

Figure 1 Aid Profile of the Median Post-Conflict Country before and after Peace Start

Figure 2 Sectoral Aid Composition of the Median Post-Conflict Country after Peace Start

Figure 3 Aid (ODA/GDP), Terms of Trade (TOT), and the Real Exchange Rate (RER) in Selected Conflict Countries before and after Peace Start

Figure 4 Impact of a one-standard-deviation Change in Real Exchange Rate (RER) Misalignment on Growth under various ODA and Financial Development Scenarios 
Table 1. Long-run Correlations of Aid, Real Exchange Rates (RER), and Terms of Trade (TOT) in Post-Conflict Countries

Country Corr. (RER, Aid) Corr. (RER, TOT) Corr. (TOT, Aid)

\begin{tabular}{|c|c|c|c|}
\hline Argentina & -0.28 & 0.74 & -0.30 \\
\hline Bangladesh & 0.11 & 0.90 & 0.22 \\
\hline Burundi & -0.80 & 0.33 & -0.50 \\
\hline Central African Rep. & 0.17 & 0.47 & 0.78 \\
\hline Chad & -0.19 & 0.57 & -0.61 \\
\hline Congo, Dem. Rep. Of & -0.42 & 0.50 & 0.50 \\
\hline Congo, Rep. Of & 0.34 & 0.62 & -0.41 \\
\hline Egypt & 0.18 & -0.38 & 0.15 \\
\hline El Salvador & -0.96 & 0.03 & -0.23 \\
\hline Ethiopia & -0.10 & -0.07 & -0.23 \\
\hline Guatemala & -0.61 & -0.42 & 0.21 \\
\hline Guinea-Bissau & 0.12 & -0.59 & 0.14 \\
\hline Indonesia & 0.99 & 0.73 & -0.08 \\
\hline Iran & -0.52 & 0.87 & -0.62 \\
\hline Israel & 0.37 & 0.00 & -0.26 \\
\hline Jordan & 0.72 & 0.63 & 0.57 \\
\hline Kenya & -0.59 & 0.61 & -0.34 \\
\hline Mali & 0.26 & 0.26 & 0.36 \\
\hline Morocco & -0.86 & 0.63 & -0.34 \\
\hline Mozambique & -0.55 & 0.23 & -0.07 \\
\hline Namibia & -0.41 & -0.20 & -0.71 \\
\hline Nicaragua & -0.26 & 0.79 & -0.53 \\
\hline Nigeria & -0.66 & 0.74 & -0.66 \\
\hline Pakistan & 0.38 & 0.50 & 0.54 \\
\hline Peru & 0.01 & 0.36 & -0.73 \\
\hline Rwanda & 0.50 & 0.71 & 0.25 \\
\hline Senegal & 0.15 & -0.19 & 0.25 \\
\hline Sierra Leone & 0.91 & 0.35 & -0.01 \\
\hline South Africa & -0.82 & 0.69 & -0.70 \\
\hline Sri Lanka & -0.60 & -0.64 & 0.10 \\
\hline Sudan & 0.67 & 0.79 & 0.64 \\
\hline Syria & 0.51 & -0.04 & 0.10 \\
\hline Thailand & 0.66 & 0.28 & 0.00 \\
\hline Turkey & -0.04 & 0.14 & -0.72 \\
\hline Uganda & -0.28 & 0.24 & -0.71 \\
\hline Zimbabwe & -0.74 & -0.46 & 0.21 \\
\hline Average correlation & -0.07 & 0.30 & -0.10 \\
\hline Standard deviation & 0.54 & 0.44 & 0.44 \\
\hline
\end{tabular}

Note:

Values in bold indicate that the correlation is significant at the 10 percent level.

The table is based on all the conflict countries that have RER misalignment data.

See Appendix A for details. 
Table 2. Performance Measures of Selected Post- Conflict Countries

\begin{tabular}{|c|c|c|c|c|c|c|c|c|c|}
\hline Country & $\begin{array}{c}\text { Year of } \\
\text { aid } \\
\text { peak }\end{array}$ & $\begin{array}{l}\text { Post- } \\
\text { conflict } \\
\text { time }\end{array}$ & $\begin{array}{c}\text { Average } \\
\text { ODA } \\
\text { (\%GDP) }\end{array}$ & $\begin{array}{c}\text { Debt ratio at } \\
\text { beginning of } \\
\text { period } \\
(\% \mathrm{GDP})^{* *}\end{array}$ & $\begin{array}{c}\text { Change in } \\
\text { debt ratio } \\
\text { (\%GDP) }\end{array}$ & $\begin{array}{c}\text { Average } \\
\text { growth in } \\
\text { nominal } \\
\text { reserve } \\
\text { money (\%) }\end{array}$ & $\begin{array}{c}\begin{array}{c}\text { Change } \\
\text { in } \\
\text { reserve } \\
\text { ratio } \\
\text { (\%GDP) }\end{array} \\
\end{array}$ & $\begin{array}{c}\text { Average } \\
\text { Inflation } \\
(\%) \\
\end{array}$ & $\begin{array}{c}\text { Average } \\
\text { growth in } \\
\text { nominal } \\
\text { exchange } \\
\text { rate }(\%) \\
\end{array}$ \\
\hline Burundi & 1988-95 & $0-7$ & 24.6 & 8.4 & -2.0 & 7.5 & 14.5 & 9.7 & 8.8 \\
\hline Ethiopia & $1992-96$ & $1-5$ & 15.5 & 41.8 & -26.1 & 5.2 & 11.3 & 5.3 & 22.4 \\
\hline Mozambique & 1996-01 & $4-9$ & 25.8 & - & - & 19.4 & 7.6 & 13.7 & 13.8 \\
\hline Nicaragua & 1993-04 & $3-14$ & 19.2 & - & - & 19.1 & 11.3 & 10.0 & 9.7 \\
\hline Rwanda & 1998-03 & $4-9$ & 18.8 & 13.7 & -9.9 & 4.3 & 4.3 & 3.4 & 9.7 \\
\hline El Salvador & 1992-01 & $0-9$ & 14.8 & 41.6 & -36.2 & 3.5 & 2.8 & 3.8 & -0.1 \\
\hline Uganda & 1995-01 & $3-9$ & 12.3 & 3.5 & 1.9 & 13.9 & 9.3 & 4.8 & 8.3 \\
\hline
\end{tabular}

Note: * Includes private remittance receipts ** or closest year available 
Table 3. Long and Short-Term Determinants of the Real Exchange Rate in the World

Estimators: Pooled mean group, Mean group, and Dynamic fixed effects (all controlling for country and time effects)

Dynamic specification: $\operatorname{ARDL}(1,1,1,0,0,1,0,1)$

Sample: annual data, 1980-2004

\begin{tabular}{|c|c|c|c|c|c|c|c|c|}
\hline \multirow[b]{2}{*}{ Variables } & \multicolumn{2}{|c|}{$\begin{array}{c}\text { Pooled Mean } \\
\text { Group }\end{array}$} & \multicolumn{2}{|c|}{ Mean Group } & \multicolumn{2}{|c|}{ Hausman Tests } & \multicolumn{2}{|c|}{$\begin{array}{c}\text { Dynamic Fixed } \\
\text { Effects }\end{array}$} \\
\hline & Coef. & St. Er. & Coef. & St.Er. & h-test & p-val & Coef. & St.Er. \\
\hline \multicolumn{9}{|l|}{$\begin{array}{l}\text { Long-Run Coefficient } \\
\end{array}$} \\
\hline Terms of Trade, logs & 0.208 & 0.031 & 0.688 & 1.038 & 0.740 & 0.390 & 0.078 & 0.055 \\
\hline Productivity, logs & 0.518 & 0.017 & 0.315 & 0.113 & 3.300 & 0.070 & 0.560 & 0.040 \\
\hline Trade Openness & -0.558 & 0.031 & -0.337 & 0.193 & 1.340 & 0.250 & -0.454 & 0.047 \\
\hline Government Consumption/GDP, logs & 2.625 & 0.258 & -23.496 & 23.438 & 1.240 & 0.270 & 0.227 & 0.399 \\
\hline Net Foreign Income/GDP & 0.004 & 0.002 & 0.071 & 0.072 & 0.870 & 0.350 & 0.013 & 0.003 \\
\hline Foreign Aid Net of Int'l Reserves/GDP & 0.002 & 0.001 & -0.007 & 0.005 & 3.410 & 0.060 & 0.002 & 0.002 \\
\hline Taxes on Non-traded Goods, logs & 2.031 & 0.403 & 8.550 & 7.317 & 0.800 & 0.370 & 1.102 & 0.730 \\
\hline \multicolumn{9}{|l|}{ Error Correction Coefficients } \\
\hline Phi & -0.20 & 0.02 & -0.70 & 0.04 & & & -0.25 & 0.01 \\
\hline \multicolumn{9}{|l|}{ Short-Run Coefficients } \\
\hline D(Terms of Trade, $\operatorname{logs})$ & 0.082 & 0.037 & -0.028 & 0.035 & & & 0.009 & 0.022 \\
\hline $\mathrm{D}$ (Productivity, logs) & 0.429 & 0.029 & 0.195 & 0.043 & & & 0.392 & 0.020 \\
\hline $\mathrm{D}($ Net Foreign Income/GDP) & 0.004 & 0.002 & 0.002 & 0.003 & & & 0.001 & 0.001 \\
\hline D(Taxes on Non-traded Goods, logs) & 0.447 & 0.470 & -0.486 & 0.489 & & & 1.093 & 0.317 \\
\hline Intercept & 0.021 & 0.029 & 0.014 & 0.099 & & & & \\
\hline No. of countries & \multicolumn{2}{|c|}{83} & \multicolumn{2}{|c|}{83} & & & \multicolumn{2}{|c|}{83} \\
\hline No. Observations & \multicolumn{2}{|c|}{1875} & \multicolumn{2}{|c|}{1875} & & & \multicolumn{2}{|c|}{1875} \\
\hline
\end{tabular}


Table 4. Real Exchange Rate Misalignment (rermis) and its Decomposition in Postconflict Countries

$$
\text { Period RERMIS Fundamentals } \begin{gathered}
\text { Error } \begin{array}{c}
\text { Policy } \\
\text { Correction Variables* Variables** }
\end{array} \text { of which foreign } \\
\text { development } \\
\text { assistance net of } \\
\text { int'l reserves/GDP }
\end{gathered}
$$

\begin{tabular}{|c|c|c|c|c|c|c|c|}
\hline \multicolumn{8}{|c|}{ Group Medians: } \\
\hline & Pre-peace & -1.03 & -0.74 & 0.61 & -0.75 & -0.56 & 0.00 \\
\hline & Peace onset & 10.56 & 1.79 & 11.21 & 1.27 & 0.90 & 11.00 \\
\hline & Post-conflict 1 & 10.25 & 0.68 & 10.52 & -0.16 & 0.16 & 0.11 \\
\hline & Post-conflict 2 & 3.89 & 2.17 & 5.51 & -0.15 & 1.18 & 0.02 \\
\hline \multicolumn{8}{|c|}{ Country Specific: } \\
\hline \multirow[t]{4}{*}{ Burundi } & Pre-peace & 35.64 & 15.33 & 17.07 & 3.16 & 10.96 & -0.27 \\
\hline & Peace onset & 11.10 & 6.35 & 2.76 & 5.07 & 3.43 & 0.52 \\
\hline & Post-conflict 1 & 4.22 & -0.86 & 5.61 & -3.47 & 2.22 & 1.22 \\
\hline & Post-conflict 2 & 10.67 & 6.39 & 4.91 & 2.50 & 3.69 & 0.92 \\
\hline \multirow[t]{4}{*}{ El Salvador } & Pre-peace & -7.49 & 1.62 & -9.11 & 3.83 & -5.85 & 0.42 \\
\hline & Peace onset & 1.17 & -3.61 & 4.77 & -3.12 & -1.44 & 0.01 \\
\hline & Post-conflict 1 & 24.68 & 0.68 & 24.89 & -3.75 & 3.03 & -0.09 \\
\hline & Post-conflict 2 & 41.07 & 7.53 & 34.78 & -0.20 & 6.19 & 0.09 \\
\hline \multirow[t]{4}{*}{ Ethiopia } & Pre-peace & 5.16 & 4.68 & 0.26 & 10.09 & -2.86 & 0.35 \\
\hline & Peace onset & 42.50 & 30.82 & 11.67 & 21.91 & 6.87 & -0.06 \\
\hline & Post-conflict 1 & -16.57 & -18.40 & 0.86 & -7.74 & -14.07 & 0.37 \\
\hline & Post-conflict 2 & -1.60 & 5.91 & -6.08 & 4.63 & 0.87 & -0.22 \\
\hline \multirow[t]{4}{*}{ Mozambique } & Pre-peace & -11.14 & -23.85 & 7.00 & -10.30 & -9.34 & 1.30 \\
\hline & Peace onset & -19.36 & -33.84 & 14.48 & -15.96 & -15.53 & 6.18 \\
\hline & Post-conflict 1 & -4.62 & -8.51 & 7.25 & -9.51 & -6.54 & 0.73 \\
\hline & Post-conflict 2 & 18.11 & 3.43 & 11.17 & 0.96 & 2.45 & -0.17 \\
\hline \multirow[t]{4}{*}{ Nicaragua } & Pre-peace & & & & & & \\
\hline & Peace onset & -16.74 & -26.48 & 16.81 & -14.11 & -25.55 & 2.36 \\
\hline & Post-conflict 1 & 11.81 & 0.72 & 43.92 & -0.10 & -9.88 & -0.23 \\
\hline & Post-conflict 2 & 6.25 & 3.34 & 2.45 & 3.17 & 32.99 & -0.78 \\
\hline \multirow[t]{4}{*}{ Rwanda } & Pre-peace & -7.81 & 13.87 & -18.46 & 13.59 & -1.79 & -1.13 \\
\hline & Peace onset & 33.51 & 3.05 & 28.97 & 0.44 & 1.28 & 2.46 \\
\hline & Post-conflict 1 & 26.57 & 2.86 & 23.58 & 1.22 & -1.13 & 0.28 \\
\hline & Post-conflict 2 & 36.29 & 9.75 & 26.55 & 0.45 & 10.56 & -0.65 \\
\hline \multirow[t]{4}{*}{ Uganda } & Pre-peace & & & & & & \\
\hline & Peace onset & 21.11 & 5.96 & 13.65 & 3.80 & 2.09 & 0.38 \\
\hline & Post-conflict 1 & 11.98 & -2.07 & 13.93 & -1.39 & 43.76 & 0.24 \\
\hline & Post-conflict 2 & 6.65 & 12.07 & -6.69 & 3.49 & 9.57 & 0.00 \\
\hline
\end{tabular}

Note: * Policy Variables are government consumption/GDP, taxes on non-traded goods, and trade openness. ${ }^{* *}$ Structural Variables are terms of trade, productivity, net foreign income/GDP, and official development assistance net of int'l reserves/GDP. RER misalignment series and subsequent decompositions are based on the estimation results of the pooled mean group estimates of table 3. Countries: see Appendix A for country list. Time span is between 1970 and 2004. 
Table 5. Economic Growth and the Role of Aid, RER Misalignment, and Financial Development in the World

Cross-country panel data consisting of non-overlapping 5-year averages spanning 19702004

Dependent variable: Growth rate of real GDP per capita

Estimation method: GMM-IV system estimator

\begin{tabular}{|c|c|c|c|}
\hline & [1] & [2] & [3] \\
\hline \multicolumn{4}{|l|}{ Control Variables } \\
\hline $\begin{array}{l}\text { Initial GDP per Capita } \\
\text { (in logs) }\end{array}$ & $\begin{array}{l}-0.0050 * * \\
(3.14)\end{array}$ & $\begin{array}{l}-0.0037^{* *} \\
(2.02)\end{array}$ & $\begin{array}{l}-0.0069^{* *} \\
(6.10)\end{array}$ \\
\hline $\begin{array}{l}\text { Initial GDP per Capita } \\
\text { Cyclical Component }\end{array}$ & $\begin{array}{l}-0.1300 * * \\
(5.83)\end{array}$ & $\begin{array}{l}-0.1404 * * \\
(8.22)\end{array}$ & $\begin{array}{c}-0.1415^{* *} \\
(8.98)\end{array}$ \\
\hline $\begin{array}{l}\text { Inflation } \\
\text { (Log of [inflation }+100])\end{array}$ & $\begin{array}{l}-0.0146 * * \\
(9.26)\end{array}$ & $\begin{array}{l}-0.0123^{* *} \\
(7.65)\end{array}$ & $\begin{array}{l}-0.0128^{* *} \\
(12.89)\end{array}$ \\
\hline $\begin{array}{l}\text { Government Expenditures/GDP } \\
\text { (in logs) }\end{array}$ & $\begin{array}{c}-0.0185^{* *} \\
(4.66)\end{array}$ & $\begin{array}{c}-0.0164 * * \\
(4.14)\end{array}$ & $\begin{array}{c}-0.0138^{* *} \\
(4.37)\end{array}$ \\
\hline $\begin{array}{l}\text { Human Capital Investment } \\
\text { (secondary enrollment, in logs) }\end{array}$ & $\begin{array}{l}0.0235 * * \\
(7.74)\end{array}$ & $\begin{array}{l}0.0171^{* *} \\
(5.20)\end{array}$ & $\begin{array}{l}0.0228^{* *} \\
(10.04)\end{array}$ \\
\hline $\begin{array}{l}\text { Rule of Law } \\
\text { (from ICRG, 0-6) }\end{array}$ & $\begin{array}{l}0.0128 * * \\
(9.12)\end{array}$ & $\begin{array}{l}0.0100^{* *} \\
(5.57)\end{array}$ & $\begin{array}{l}0.0116^{* *} \\
(8.32)\end{array}$ \\
\hline $\begin{array}{l}\text { Trade Openness } \\
\text { (trade volume/GDP, in logs) }\end{array}$ & $\begin{array}{l}0.0197 * * \\
(6.93)\end{array}$ & $\begin{array}{l}0.0143^{* *} \\
(5.47)\end{array}$ & $\begin{array}{l}0.0137^{* *} \\
(6.45)\end{array}$ \\
\hline \multicolumn{4}{|l|}{ Aid, RERMIS, and Financial Development } \\
\hline $\begin{array}{l}\text { Official Development Assistance/GDP } \\
\text { (beginning of period) }\end{array}$ & $\begin{array}{l}0.0017 * * \\
(6.76)\end{array}$ & $\begin{array}{l}0.0008^{* *} \\
(2.31)\end{array}$ & $\begin{array}{l}0.0010^{* *} \\
(3.63)\end{array}$ \\
\hline $\begin{array}{l}\text { Official Development Assistance/GDP squared } \\
\text { (beginning of period) }\end{array}$ & $\begin{array}{l}0.0000^{* *} \\
(3.58)\end{array}$ & $\begin{array}{c}0.0000^{*} \\
(1.78)\end{array}$ & $\begin{array}{l}0.0000^{* *} \\
(2.17)\end{array}$ \\
\hline $\begin{array}{l}\text { RER Misalignment } \\
\text { (\% difference } b / w \log \text { REER and its equilibrium) }\end{array}$ & $\begin{array}{l}-0.0117 * * \\
(4.53)\end{array}$ & $\begin{array}{l}-0.1236^{* *} \\
(5.68)\end{array}$ & $\begin{array}{l}-0.1044^{* *} \\
\quad(5.03)\end{array}$ \\
\hline Peace Onset & $\begin{array}{r}0.0077 \\
(1.48)\end{array}$ & $\begin{array}{r}0.0008 \\
(0.12)\end{array}$ & \\
\hline Post-conflict 1 & $\begin{array}{l}0.0164 * * \\
(4.82)\end{array}$ & $\begin{array}{r}0.0042 \\
(0.82)\end{array}$ & \\
\hline Post-conflict 2 & $\begin{array}{l}0.0213^{* *} \\
(3.31)\end{array}$ & $\begin{array}{r}-0.0073 \\
(0.75)\end{array}$ & \\
\hline $\begin{array}{l}\text { Financial Development } \\
\text { (Liquid liabilities / GDP, in logs) }\end{array}$ & $\begin{array}{r}-0.0005 \\
(1.35) \\
\end{array}$ & $\begin{array}{l}0.0042^{* *} \\
(4.70)\end{array}$ & $\begin{array}{c}0.0036^{* *} \\
(4.32)\end{array}$ \\
\hline
\end{tabular}


Table 5. Economic Growth and the Role of Aid, RER Misalignment, and Financial Development in the World (cont.)

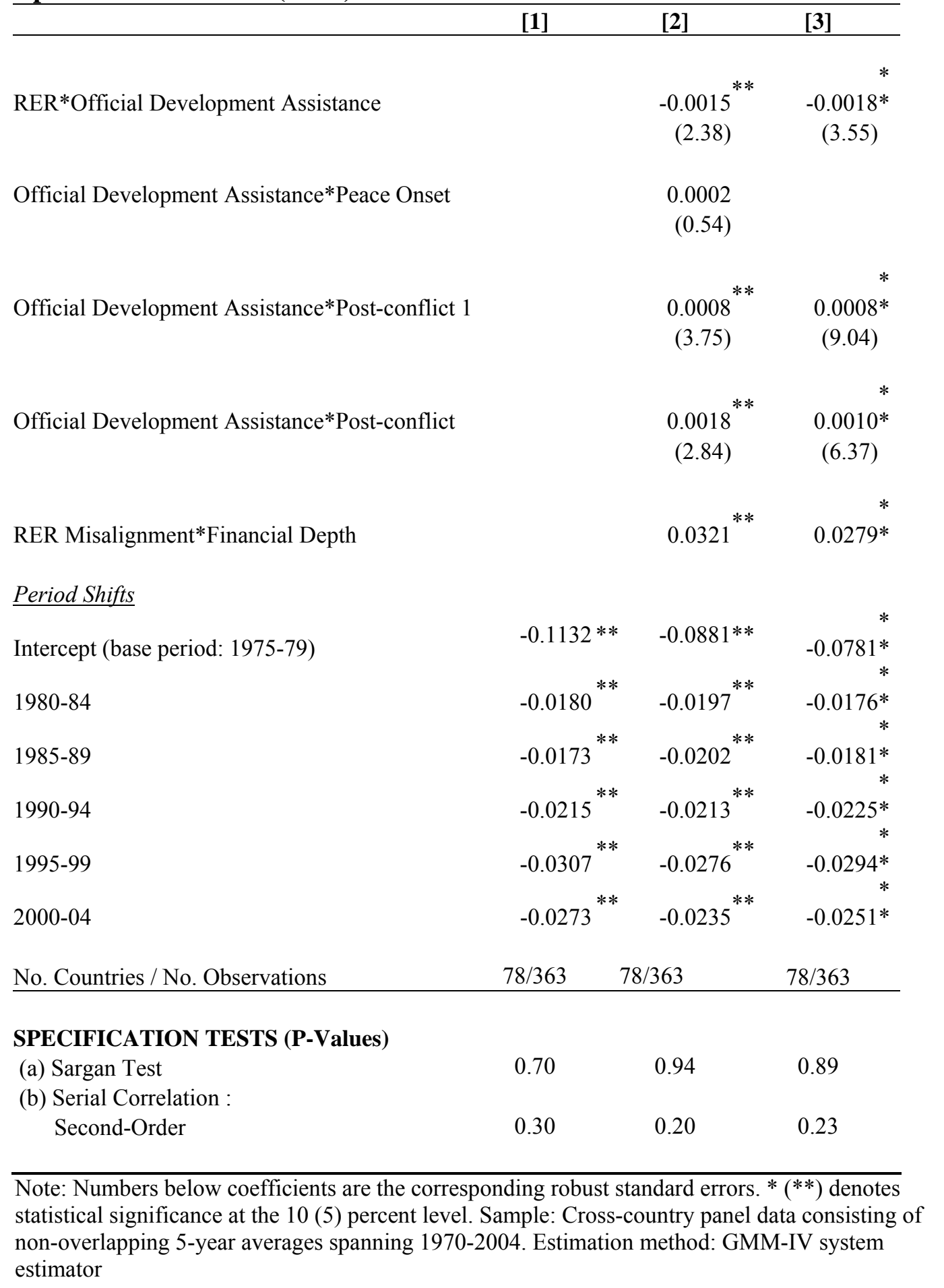


Figure 1. Aid Profile of the Median Post-Conflict Country before and after Peace Start

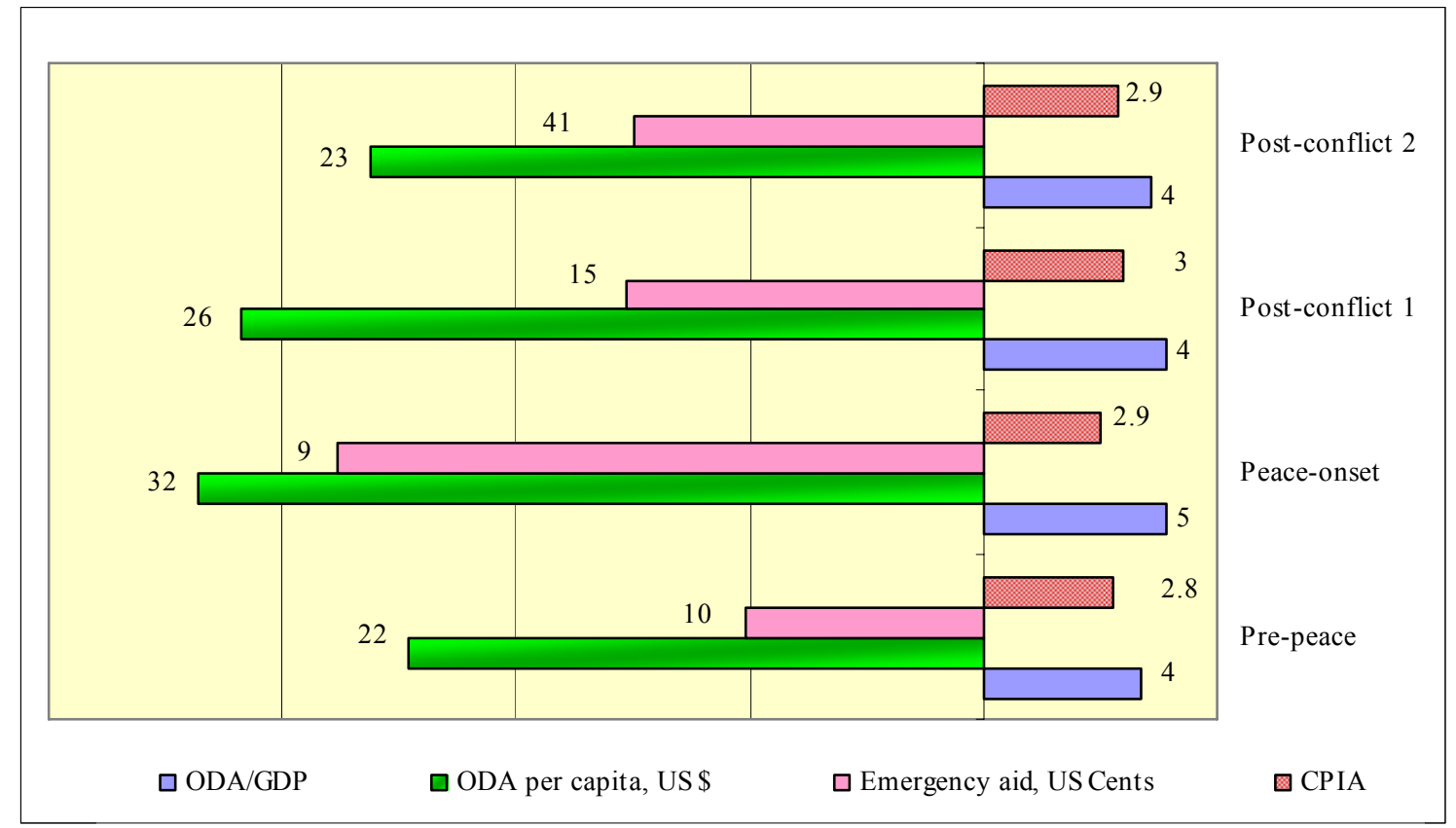

Note: The figure is based on all the conflict countries that have RER misalignment data. See Appendix A for details 
Figure 2. Sectoral Aid Composition of the Median Post-Conflict Country after Peace Start

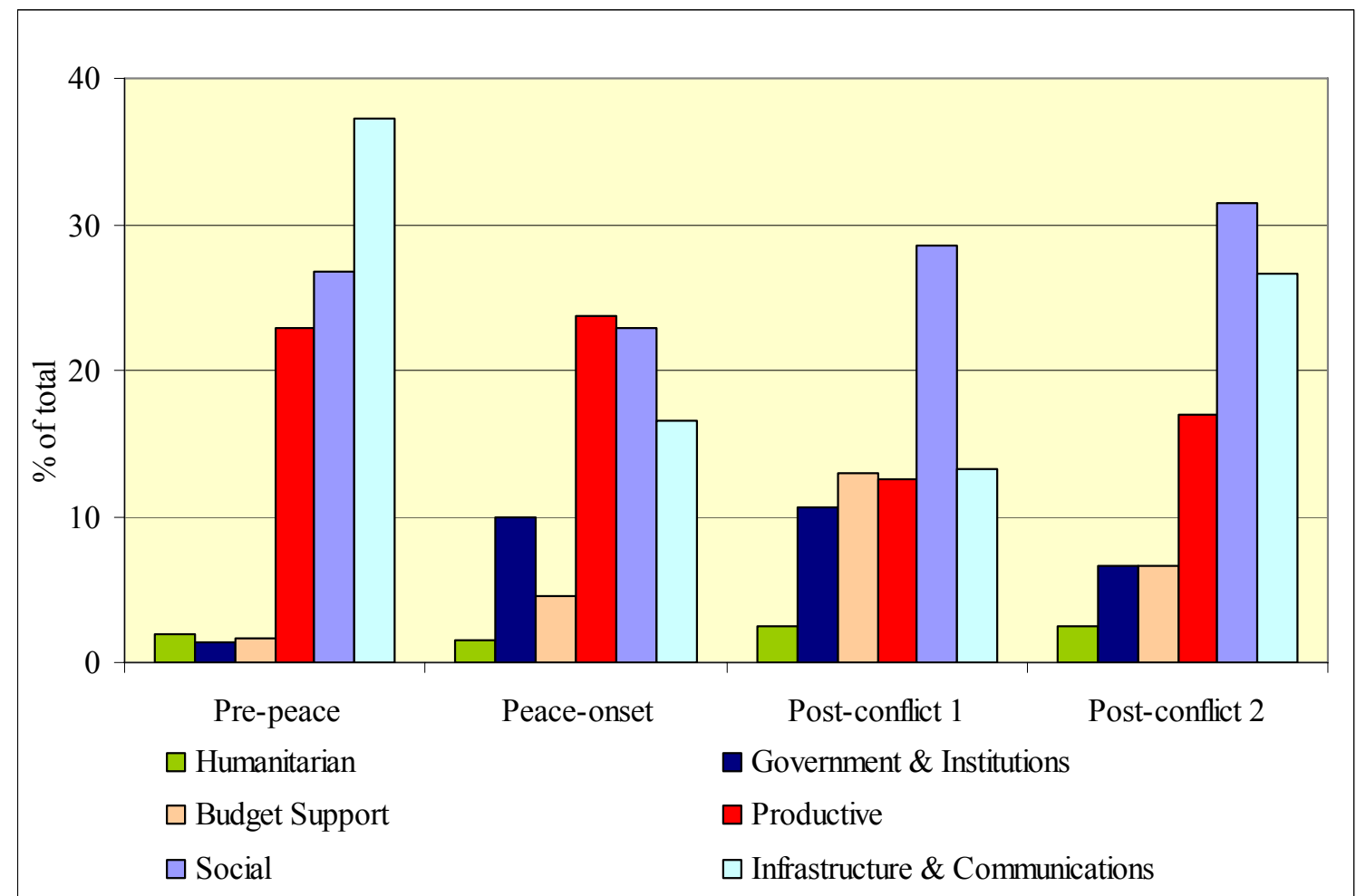

Note: The productive sector is made up of agriculture, industry, banking, and business. The social sector is made up of education, health, population, and water. The infrastructure and communications sector is made up of transport, communications, and energy. The figure is based on all the conflict countries that have RER misalignment data. See Appendix A for details. 
Figure 3. Aid (ODA/GDP), Terms of Trade (TOT), and the Real Exchange Rate (RER) in Selected Conflict Countries before and after Peace Start
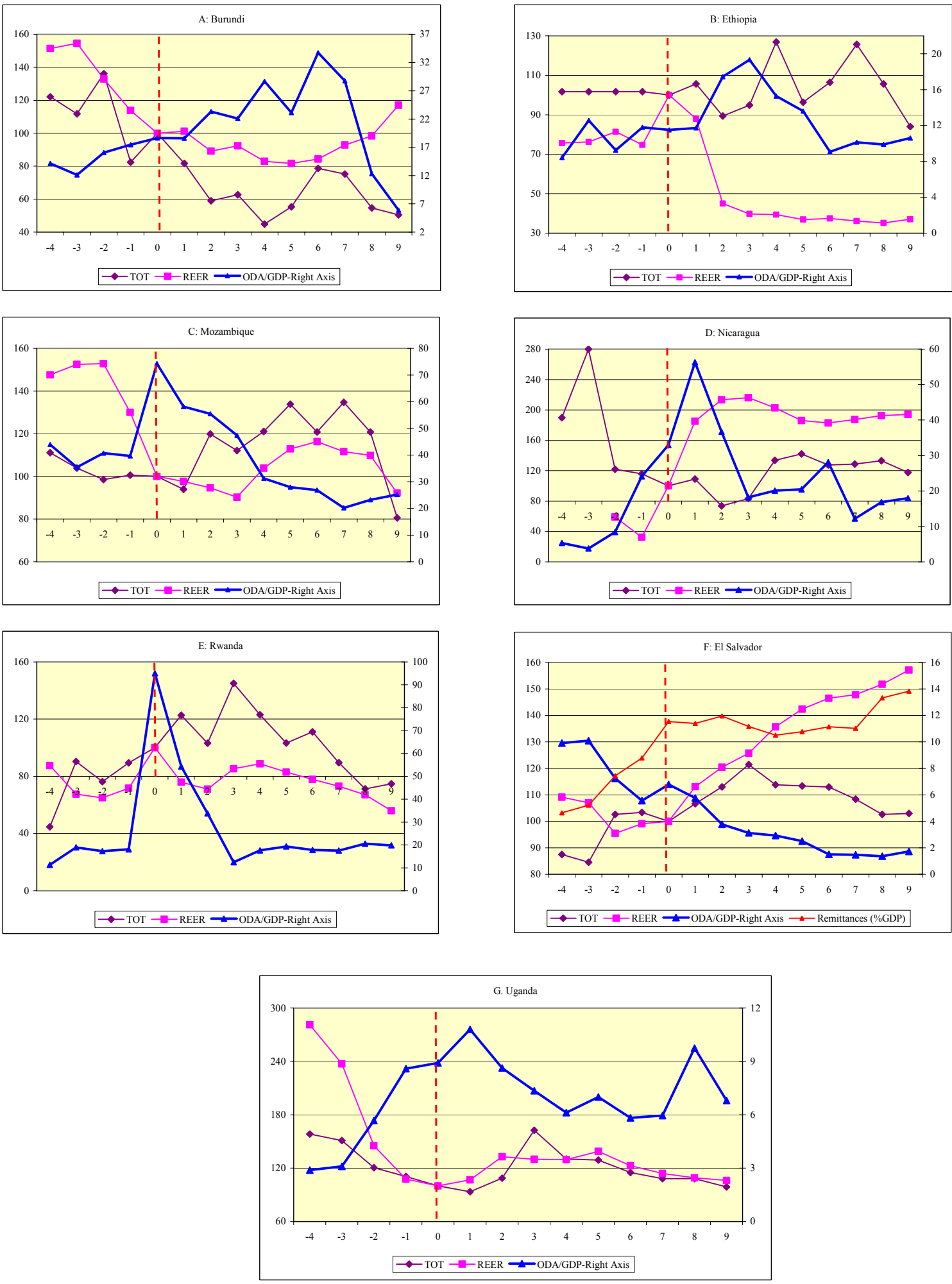
Figure 4. Impact of a one-standard-deviation Change in Real Exchange Rate (RER) Misalignment on Growth under various ODA and Financial Development Scenarios

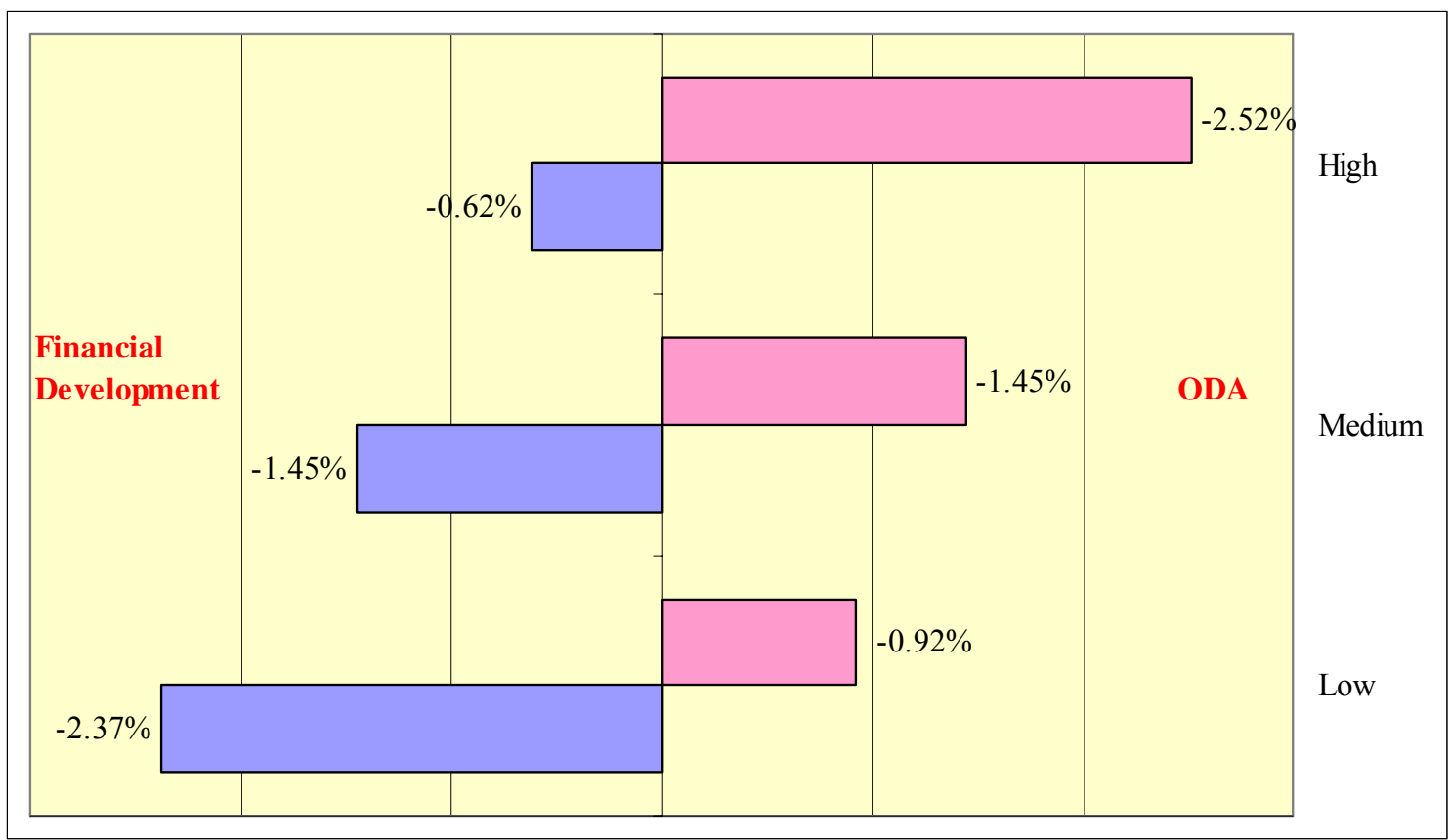

Note: Simulations are based on the sample used for the growth regressions. See appendix A for a list of countries. 


\section{Appendix A: Country and Period Coverage}

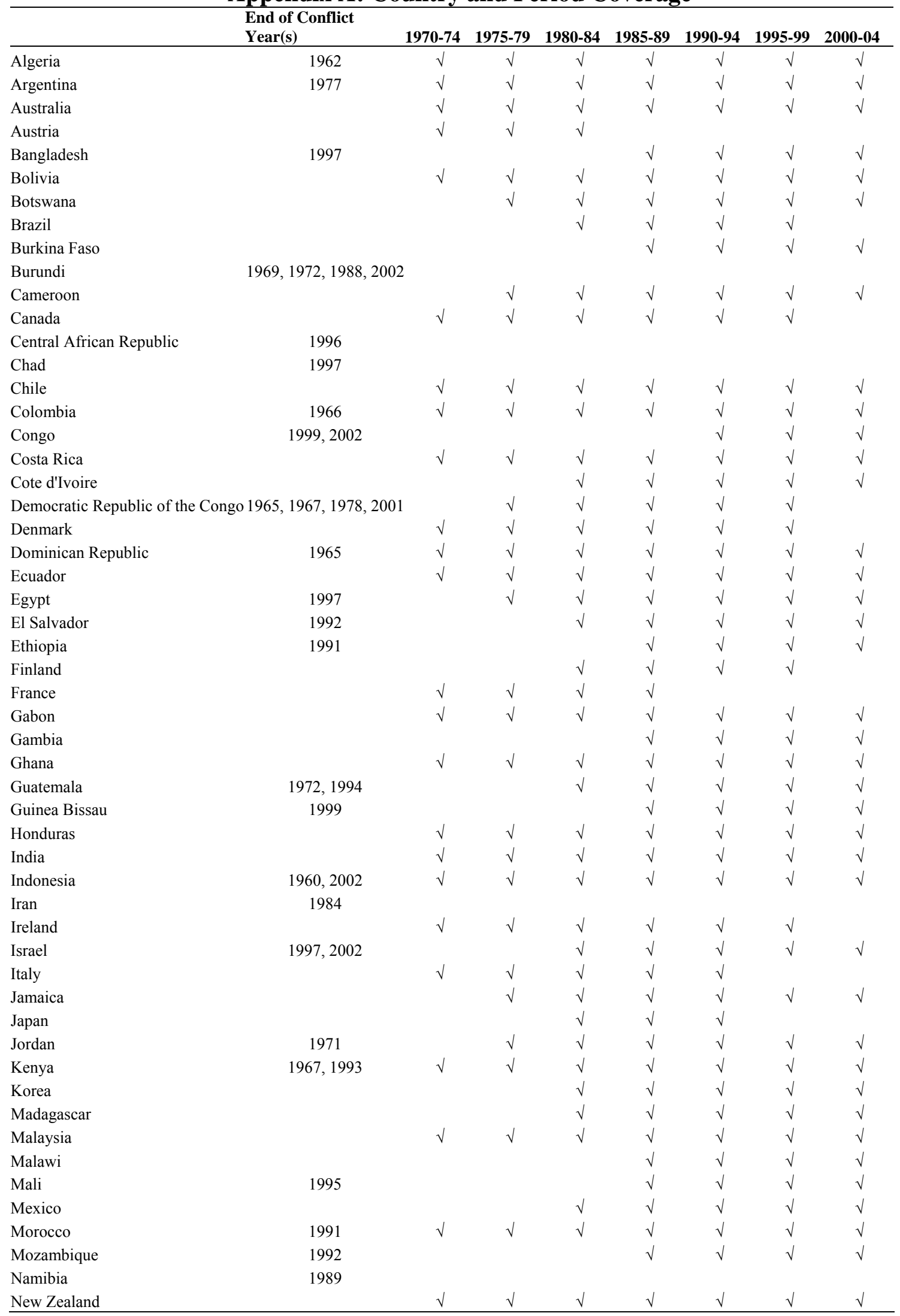


Appendix A: Country and Period Coverage (cont.)

\begin{tabular}{|c|c|c|c|c|c|c|c|c|}
\hline & $\begin{array}{c}\text { End of Conflict } \\
\text { Year(s) }\end{array}$ & 1970-74 & 1975-79 & $1980-84$ & 1985-89 & 1990-94 & 1995-99 & 2000-04 \\
\hline Nicaragua & 1979,1990 & & & $\sqrt{ }$ & $\sqrt{ }$ & $\sqrt{ }$ & $\sqrt{ }$ & $\sqrt{ }$ \\
\hline Niger & & & & & $\sqrt{ }$ & $\sqrt{ }$ & $\sqrt{ }$ & $\sqrt{ }$ \\
\hline Nigeria & 1970,1984 & $\sqrt{ }$ & $\sqrt{ }$ & $\sqrt{ }$ & $\sqrt{ }$ & $\sqrt{ }$ & $\sqrt{ }$ & $\sqrt{ }$ \\
\hline Norway & & $\sqrt{ }$ & $\sqrt{ }$ & $\sqrt{ }$ & $\sqrt{ }$ & $\sqrt{ }$ & $\sqrt{ }$ & $\sqrt{ }$ \\
\hline Pakistan & 1971, 1977, 2002 & $\sqrt{ }$ & $\sqrt{ }$ & $\sqrt{ }$ & $\sqrt{ }$ & $\sqrt{ }$ & $\sqrt{ }$ & $\sqrt{ }$ \\
\hline Panama & & & & $\sqrt{ }$ & $\sqrt{ }$ & $\sqrt{ }$ & $\sqrt{ }$ & $\sqrt{ }$ \\
\hline Papua New Guinea & 1998 & & $\sqrt{ }$ & $\sqrt{ }$ & $\sqrt{ }$ & $\sqrt{ }$ & $\sqrt{ }$ & \\
\hline Paraguay & & $\sqrt{ }$ & $\sqrt{ }$ & $\sqrt{ }$ & $\sqrt{ }$ & $\sqrt{ }$ & $\sqrt{ }$ & $\sqrt{ }$ \\
\hline Peru & 1996 & $\sqrt{ }$ & $\sqrt{ }$ & $\sqrt{ }$ & $\sqrt{ }$ & $\sqrt{ }$ & $\sqrt{ }$ & $\sqrt{ }$ \\
\hline Philippines & & $\sqrt{ }$ & $\sqrt{ }$ & $\sqrt{ }$ & $\sqrt{ }$ & $\sqrt{ }$ & $\sqrt{ }$ & $\sqrt{ }$ \\
\hline Rwanda & 1964, 1994, 2001 & & & & & & & \\
\hline Senegal & 1999 & $\sqrt{ }$ & $\sqrt{ }$ & $\sqrt{ }$ & $\sqrt{ }$ & $\sqrt{ }$ & $\sqrt{ }$ & $\sqrt{ }$ \\
\hline Sierra Leone & 2001 & & & & $\sqrt{ }$ & $\sqrt{ }$ & $\sqrt{ }$ & $\sqrt{ }$ \\
\hline South Africa & 1994 & & & & & & & \\
\hline Sri Lanka & 1971,2002 & $\sqrt{ }$ & $\sqrt{ }$ & $\sqrt{ }$ & $\sqrt{ }$ & $\sqrt{ }$ & $\sqrt{ }$ & $\sqrt{ }$ \\
\hline Sudan & 1972,2002 & $\sqrt{ }$ & $\sqrt{ }$ & $\sqrt{ }$ & $\sqrt{ }$ & $\sqrt{ }$ & $\sqrt{ }$ & $\sqrt{ }$ \\
\hline Sweden & & & & $\sqrt{ }$ & $\sqrt{ }$ & $\sqrt{ }$ & $\sqrt{ }$ & $\sqrt{ }$ \\
\hline Switzerland & & $\sqrt{ }$ & $\sqrt{ }$ & $\sqrt{ }$ & $\sqrt{ }$ & $\sqrt{ }$ & $\sqrt{ }$ & $\sqrt{ }$ \\
\hline Syria & 1982 & $\sqrt{ }$ & $\sqrt{ }$ & $\sqrt{ }$ & $\sqrt{ }$ & & & \\
\hline Thailand & 1982 & $\sqrt{ }$ & $\sqrt{ }$ & $\sqrt{ }$ & $\sqrt{ }$ & $\sqrt{ }$ & $\sqrt{ }$ & $\sqrt{ }$ \\
\hline Togo & & & $\sqrt{ }$ & $\sqrt{ }$ & $\sqrt{ }$ & $\sqrt{ }$ & $\sqrt{ }$ & $\sqrt{ }$ \\
\hline Trinidad \& Tobago & & & $\sqrt{ }$ & $\sqrt{ }$ & $\sqrt{ }$ & $\sqrt{ }$ & $\sqrt{ }$ & $\sqrt{ }$ \\
\hline Tunisia & & & & $\sqrt{ }$ & $\sqrt{ }$ & $\sqrt{ }$ & $\sqrt{ }$ & $\sqrt{ }$ \\
\hline Turkey & 1999 & $\sqrt{ }$ & $\sqrt{ }$ & $\sqrt{ }$ & $\sqrt{ }$ & $\sqrt{ }$ & $\sqrt{ }$ & $\sqrt{ }$ \\
\hline Uganda & 1966, 1979, 1987, 1992 & & & & $\sqrt{ }$ & $\sqrt{ }$ & $\sqrt{ }$ & $\sqrt{ }$ \\
\hline United States & & $\sqrt{ }$ & $\sqrt{ }$ & $\sqrt{ }$ & $\sqrt{ }$ & $\sqrt{ }$ & $\sqrt{ }$ & $\sqrt{ }$ \\
\hline Uruguay & & $\sqrt{ }$ & $\sqrt{ }$ & $\sqrt{ }$ & $\sqrt{ }$ & $\sqrt{ }$ & $\sqrt{ }$ & $\sqrt{ }$ \\
\hline Venezuela & & $\sqrt{ }$ & $\sqrt{ }$ & $\sqrt{ }$ & $\sqrt{ }$ & $\sqrt{ }$ & $\sqrt{ }$ & $\sqrt{ }$ \\
\hline Zambia & & & & & $\sqrt{ }$ & $\sqrt{ }$ & $\sqrt{ }$ & $\sqrt{ }$ \\
\hline Zimbabwe & 1979,1987 & & $\sqrt{ }$ & $\sqrt{ }$ & $\sqrt{ }$ & $\sqrt{ }$ & $\sqrt{ }$ & $\sqrt{ }$ \\
\hline
\end{tabular}

Note: End of conflict years are only reported for those countries for which we have RER misalignment data in the period $1960-04$. These are used for the analysis in sections1-4 of the paper. Checkmarks indicate that the country-period combination is included in the growth regressions. 


\section{Appendix B: Definitions and Sources of Variables Used in Regression Analysis}

\begin{tabular}{|c|c|c|}
\hline Variable & Definition and Construction & Source \\
\hline $\begin{array}{l}\text { Official Development } \\
\text { Assistance }\end{array}$ & $\begin{array}{l}\text { Ratio of official development assistance (current USD) } \\
\text { to GDP (current USD). }\end{array}$ & WDI (2006) \\
\hline Emergency Aid & & $\begin{array}{l}\text { Development Assistance Committee } \\
\text { (OECD) (2006) }\end{array}$ \\
\hline CPIA & $\begin{array}{l}\text { Index that assesses a country's economic management, } \\
\text { structural policies, policies for social inclusion/equity, } \\
\text { and public sector management and institutions. }\end{array}$ & World Bank \\
\hline Sectoral Aid & On a commitment basis & Credit Reporting System (OECD) (2006) \\
\hline $\begin{array}{l}\text { Real effective exchange } \\
\text { rate }\end{array}$ & $\begin{array}{l}\text { Real effective exchange rate is the nominal effective } \\
\text { exchange rate (a measure of the value of a currency } \\
\text { against a weighted average of several foreign } \\
\text { currencies) divided by a price deflator or index of costs. }\end{array}$ & $\begin{array}{l}\text { International Financial Statistics, (2006) } \\
\text { supplemented with internal data from } \\
\text { IMF Information Notice System. }\end{array}$ \\
\hline Terms of Trade & $\begin{array}{l}\text { The terms of trade index shows the national accounts } \\
\text { exports price index divided by the imports price index. }\end{array}$ & $\begin{array}{l}\text { World Development Indicators (2005, } \\
\text { 2006) and Loayza et al. (2005) }\end{array}$ \\
\hline Post-conflict Episodes & $\begin{array}{l}\text { Pre-peace: years }-4 \text { to }-1 \text { prior to the end of conflict } \\
\text { which is denoted as time } 0 \text {. Peace onset: years } 0 \text { and } 1 \text {; } \\
\text { post-conflict } 1 \text { : years } 2 \text { until } 5 \text {; post-conflict } 2 \text { : years } 6 \\
\text { until } 9 \text {. }\end{array}$ & $\begin{array}{l}\text { Authors' construction using conflict data } \\
\text { from Sambanis (2004) and } \\
\text { complementing them with data from } \\
\text { armed conflict dataset of PRIO for the } \\
\text { years 2002-04. www.prio.no }\end{array}$ \\
\hline Debt ratio & Debt/GDP measured in nominal USD. & WDI (2006) \\
\hline Growth in reserve money & $\begin{array}{l}\text { Log difference of nominal reserve money (local } \\
\text { currency). }\end{array}$ & International Financial Statistics, (2006). \\
\hline Change in reserve ratio & $\begin{array}{l}\text { Difference of ratio of international reserves to GDP } \\
\text { between years } t \text { and } t-1\end{array}$ & WDI (2006) \\
\hline Inflation & Inflation as measured by the consumer price index . & WDI (2006) \\
\hline $\begin{array}{l}\text { Growth in nominal } \\
\text { exchange rate }\end{array}$ & $\begin{array}{l}\text { Log difference of nominal exchange rates between years } \\
t \text { and } t-1\end{array}$ & WDI (2006) \\
\hline Productivity & $\begin{array}{l}\text { Ratio of per capita GDP at factor cost in United States } \\
\text { dollars over average GDP at factor cost in United States } \\
\text { dollars for Industrial Countries. }\end{array}$ & $\begin{array}{l}\text { Authors' construction using World } \\
\text { Development Indicators, } 2005\end{array}$ \\
\hline Openness & $\begin{array}{l}\text { Residual of a regression of the log of the ratio of exports } \\
\text { and imports (in current local currency units) to GDP (in } \\
\text { local currency units), on the logs of area and population, } \\
\text { and dummies for oil exporting and for landlocked } \\
\text { countries }\end{array}$ & $\begin{array}{l}\text { World Development Indicators, } 2004 \text { and } \\
\text { Loayza et al. (2005) }\end{array}$ \\
\hline $\begin{array}{l}\text { Government } \\
\text { Consumption }\end{array}$ & $\begin{array}{l}\text { Ratio of government consumption to GDP (current } \\
\text { local currency units) }\end{array}$ & $\begin{array}{l}\text { Authors' construction using International } \\
\text { Financial Statistics, December } 2004 \text { CD- } \\
\text { ROM Release, World Development } \\
\text { Indicators, 2004, and Africa Live } \\
\text { Database (World Bank), } 2004\end{array}$ \\
\hline
\end{tabular}




\section{Appendix B: Definitions and Sources of Variables Used in Regression Analysis (cont.)}

\begin{tabular}{|c|c|}
\hline Variable & Definition and Construction \\
\hline \multicolumn{2}{|l|}{ Net Foreign Income } \\
\hline $\begin{array}{l}\text { Taxes on Non-traded } \\
\text { Goods }\end{array}$ & $\log [1+\operatorname{taxes} / \mathrm{GDP}]$ \\
\hline \multicolumn{2}{|l|}{ Variables Used in } \\
\hline \multicolumn{2}{|l|}{ Growth Regressions } \\
\hline GDP per capita growth & Log difference of real GDP per capita. \\
\hline Initial GDP per capita & $\begin{array}{l}\text { Initial value of ratio of total real GDP to total } \\
\text { population. }\end{array}$ \\
\hline $\begin{array}{l}\text { Initial GDP per Capita } \\
\text { Cyclical Component }\end{array}$ & $\begin{array}{l}\text { Difference between the logarithm of actual GDP per } \\
\text { capita and the logarithm of potential (trend) GDP. The } \\
\text { Hodrik-Prescott filter was used for the decomposition. }\end{array}$ \\
\hline Inflation & The logarithm of 100 plus the inflation rate. \\
\hline Government & Ratio of government expenditures (in local currency) to \\
\hline Expenditures & GDP (in local currency). \\
\hline
\end{tabular}

Human Capital

Investment

Rule of Law

Trade Openness

Real Exchange Rate Misalignment

Post-conflict Episodes

Financial Depth
Ratio of total secondary enrollment, regardless of age, to the population of the age group that officially corresponds to that level of education.

Presence of law and order. Range is between 0 and 6 .

Ratio of exports and imports (in local currency) to GDP (in local currency).

Percentage difference between real effective exchange rate and its estimated equilibrium value.

Peace onset: dummy variable equal to 1 for the period when the war ended and 0 otherwise; post-conflict 1 and 2 are the two periods immediately after the end of the war

Ratio of liquid liabilities to GDP. Liquid liabilities are also known as broad money or M3.
World Development Indicators, 2004, Africa Live Database, 2004, and Government Finance Statistics, 2004

Authors' construction using data from World Development Indicators (WDI), The World Bank (2006).

Authors' construction WDI, The World Bank (2006).

Authors' calculations using data from WDI (2006)

Author's calculations with data from WDI (2006)

Data come primarily from International Financial Statistics (IFS), 2006; when missing, they are complemented with data from WDI (2006) and UN National Accounts Statistics (2006)

Easterly and Sewadeh (2002), WDI (2006), UNESCO (2006).

International Country Risk Guide (ICRG), Political Risk Services. www.icrgonline.com

Data come primarily from International Financial Statistics (IFS), 2006; when missing, they are complemented with data from WDI (2006) and UN National Accounts Statistics (2006)

Authors' calculations. See Appendix C for the methodology.

Authors' construction using conflict data from Sambanis (2004) and complementing them with data from armed conflict dataset of PRIO for the years 2002-04. www.prio.no

WDI (2006) 


\section{Appendix C \\ Computing the Equilibrium Real Exchange Rate and RER Misalignment Indexes}

In order to describe our methodology to determine the equilibrium RER it is useful to collapse all of its determinants into a category we call fundamentals. Let $e_{i t}$ be the $\log$ of the observed real exchange rate for country $i$ in time $t$. Then we can write the equilibrium RER equation as:

$$
e_{t}^{i}=\hat{\delta}_{0}^{i}+\hat{\beta}^{\prime} F_{t}^{i}+\hat{\varepsilon}_{t}^{i}
$$

where $i$ denotes a country and $\varepsilon_{t}^{i}$ is a stochastic innovation or short-term fluctuation. Note that the intercept varies across countries.

Let the equilibrium RER be as follows:

$$
\widetilde{e}_{t}^{i}=\widetilde{\delta}_{o}^{i}+\hat{\beta}^{\prime} \widetilde{F}_{t}^{i}
$$

where $\widetilde{F}_{t}^{i}$ refers to sustainable fundamentals, given by the permanent components of the fundamentals and $\widetilde{\delta}_{0}^{i}$ is a scaled country-specific intercept to be identified below.

Under the assumption that the model is correctly specified, the real exchange rate misalignment is simply given by subtracting the equilibrium from the observed RER:

$$
\operatorname{rermis}_{i t}=e_{t}^{i}-\widetilde{e}_{t}^{i}=\left(\delta_{0}^{i}-\hat{\delta}_{0}^{i}\right)+\hat{\beta}^{\prime}\left(F_{t}^{i}-\widetilde{F}_{t}^{i}\right)+\hat{\varepsilon}_{t}^{i}
$$

The scaled intercept of the equilibrium RER $\left(\hat{\delta}_{0}^{i}\right)$ must satisfy the following identification condition of RER misalignment:

$$
E_{t}\left(\operatorname{rermis}_{i t}\right)=E_{t}\left[\left(\delta_{0}^{i}-\hat{\delta}_{0}^{i}\right)+\hat{\beta}^{\prime}\left(F_{t}^{i}-\widetilde{F}_{t}^{i}\right)+\hat{\varepsilon}_{t}^{i}\right\rfloor=0
$$

This condition requires that, for any given country, the expected value of the RER misalignment across time must be equal to zero. This is because eventually the RER must revert to it equilibrium level; otherwise it will not be "misalignment" but a permanent phenomenon. Though the expected value of the transitory components of the fundamentals (second right hand side term) should be zero, we do not make that restriction to allow for potential misspecification of the decomposition procedure ${ }^{30}$.

\footnotetext{
${ }^{30}$ We will show below that the expression for the equilibrium RER is the same whether or not we assume the expected values of the transitory fundamentals to be zero. Moreover, under the general case, the equation for misalignment generates the one with the expected value equal to zero as a special case.
} 
Noting that the first right hand side term is time-invariant, we have the following sample estimate for the equilibrium intercept term:

$$
\hat{\delta}_{0}^{i}=\delta_{0}^{i}+\hat{\beta}^{\prime}\left[\frac{1}{n} \sum_{t}\left(F_{t}^{i}-\widetilde{F}_{t}^{i}\right)\right]+\overline{\hat{\varepsilon}}_{t}^{i}
$$

Note that though the panel estimation requires that $E_{t, i}\left[\hat{\varepsilon}_{t}^{i}\right]=0, E_{t}\left[\hat{\varepsilon}_{t}^{i}\right]$ is not, in general, equal to zero and can be estimated by the mean of the residuals $\overline{\hat{\varepsilon}}^{i}=\frac{1}{n} \sum_{t} \hat{\varepsilon}_{t}^{i}=\frac{1}{n} \sum_{t} e_{t}^{i}-\hat{\delta}_{0}^{i}-\hat{\beta}^{\prime}\left(\frac{1}{n} \sum_{t} F_{t}^{i}\right)$ (from equation 1). Substituting for the mean residual in equation (5), we have the final expression for the equilibrium intercept:

$$
\widetilde{\delta}_{0}^{i}=\bar{e}^{i}+\hat{\beta}^{\prime}\left(\bar{F}^{i}-\overline{\widetilde{F}}^{i}\right)-\hat{\beta}^{\prime} \bar{F}^{i}=\bar{e}^{i}-\hat{\beta}^{\prime} \bar{F}^{i},
$$

where $\bar{e}^{i}, F^{i}$ and $\bar{F}^{i}$, respectively, denote the mean values (over time) of the actual RER, the fundamentals, and their corresponding permanent components.

Using equations (6) and (2) gives us the ultimate expression for the equilibrium RER index:

$$
\widetilde{e}_{t}^{i}=\bar{e}^{i}+\hat{\beta}^{\prime}\left(\widetilde{F}_{t}^{i}-\overline{\widetilde{F}}^{i}\right)
$$

This expression states that, for any given country $i$, the RER equilibrium index must be equal to the average of the observed RER over the estimation period plus (minus) a component reflecting equilibrium appreciation (depreciation), where an equilibrium appreciation (depreciation) is required when the weighted permanent component of the fundamentals in time $t$ is larger (smaller) than the corresponding average over the estimation period (second right hand side term).

Subtracting the above index from the observed RER gives the corresponding expression for RER misalignment ${ }^{31}$ :

$$
\operatorname{rermis}_{t}^{i}=\left(e_{t}^{i}-\bar{e}^{i}\right)-\hat{\beta}^{\prime}\left(\widetilde{F}_{t}^{i}-\overline{\widetilde{F}}^{i}\right)
$$

\footnotetext{
${ }^{31}$ Under the assumption that $\left.E_{t} \mid \hat{\beta}^{\prime}\left(F_{t}^{i}-\widetilde{F}_{t}^{i}\right)\right]=0$, the corresponding expression for the equilibrium intercept is given by $\widetilde{\delta}_{0}^{i}=\bar{e}^{i}-\hat{\beta}^{\prime} F^{i}$. However, since $\bar{F}^{i}=\widetilde{F}^{i}+\frac{1}{n} \sum\left(F_{t}^{i}-\widetilde{F}_{t}^{i}\right)$ and the second RHS term is equal to zero by assumption/construction, the expression for the intercept is the same under both cases.

Therefore, the expressions for the equilibrium RER (equation 7) as well as misalignment (equation 8) also remain the same.
} 
Like the equilibrium RER index, the expression for RER misalignment is also very intuitive. It suggests that, at any point in time, if the difference between the RER at time $t$ and the average RER is in excess of the equilibrium appreciation component the exchange rate is overvalued at time $t$, and the extent of the overvaluation is given by the net difference. This expression also suggests that depending on the size of the equilibrium appreciation component, a higher than average real exchange rate is compatible with overvaluation (rermis $>0$ ), undervaluation $($ rermis $<0)$ or perfect equilibrium (rermis $=0$ ).

If the permanent components of the fundamentals are time-invariant, the second term in the RHS of equations 7 and 8 will be zero. The equilibrium RER will, therefore, be equal to the mean of the observed RER and the misalignment will be given by the deviation from the mean RER. This will be consistent with a variant of the PPP model. However, the PPP restriction is neither corroborated by theory nor the time series characteristics of the fundamentals, especially for the case of developing countries.

\section{Decomposing RER Misalignment}

Equation (8) is all what we need for constructing the equilibrium RER index and the corresponding aggregate index of RER misalignment. However, further manipulation of this equation would provide further insight for policy analysis. Using equation (1) to substitute for the first RHS term of equation 8 we have ${ }^{32}$ :

$$
\operatorname{rermis}_{t}^{i}=\hat{\beta}^{\prime}\left[\left(F_{t}^{i}-\widetilde{F}_{t}^{i}\right)-\left(\bar{F}^{i}-\overline{\widetilde{F}}^{i}\right)\right]+\left(\hat{\varepsilon}_{t}^{i}-\overline{\hat{\varepsilon}}^{i}\right)=\hat{\beta}^{\prime}\left(F_{t}^{T^{i}}-\frac{1}{n} \sum_{t} F_{t}^{T^{i}}\right)+\left(\hat{\varepsilon}_{t}^{i}-\overline{\hat{\varepsilon}}^{i}\right)
$$

where a "T" over a variable indicates its "transitory" component. This expression suggests that RER misalignment can be accounted for by a fundamental component and an error-correction component. For example, the RER will be overvalued in time $t$ if the "weighted" transitory component of the fundamentals is larger than the average and that deeper than average error-correction is required. The latter reflects the effect of short-run macroeconomic policies, which are not part of the long-run fundamentals but may influence the RER in the short-run (e.g. rate of monetary expansion, nominal devaluation).

${ }^{32}$ Note that if $\frac{1}{n} \sum_{t} F_{i t}^{T}=0$ the expression for rermis becomes a special case of equation 8. 